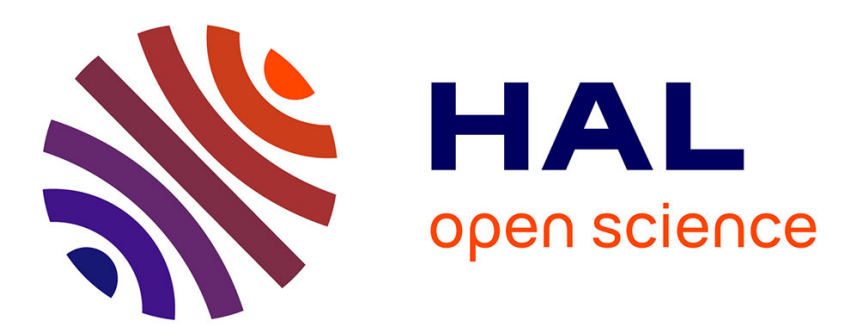

\title{
Exponential Molecular Amplification by H2O2-Mediated Autocatalytic Deprotection of Boronic Ester Probes to Redox Cyclers
}

\author{
Justine Pallu, Charlie Rabin, Geordie Creste, Mathieu Branca, François
}

Mavré, Benoit Limoges

\section{To cite this version:}

Justine Pallu, Charlie Rabin, Geordie Creste, Mathieu Branca, François Mavré, et al.. Exponential Molecular Amplification by H2O2-Mediated Autocatalytic Deprotection of Boronic Ester Probes to Redox Cyclers. Chemistry - A European Journal, 2019, 25 (31), pp.7534-7546. 10.1002/chem.201900627 . hal-02390846

\section{HAL Id: hal-02390846 https://hal.science/hal-02390846}

Submitted on 6 Dec 2019

HAL is a multi-disciplinary open access archive for the deposit and dissemination of scientific research documents, whether they are published or not. The documents may come from teaching and research institutions in France or abroad, or from public or private research centers.
L'archive ouverte pluridisciplinaire HAL, est destinée au dépôt et à la diffusion de documents scientifiques de niveau recherche, publiés ou non, émanant des établissements d'enseignement et de recherche français ou étrangers, des laboratoires publics ou privés. 


\title{
Exponential Molecular Amplification by $\mathrm{H}_{2} \mathrm{O}_{2}$-mediated Autocatalytic Deprotection of Boronic Ester Probes to Redox Cyclers
}

\author{
Justine Pallu, Charlie Rabin, Geordie Creste, Mathieu Branca, ${ }^{*}$ François Mavré, ${ }^{*}$ Benoît Limoges ${ }^{\star}[\mathrm{a}]$
}

\begin{abstract}
Herein, we describe a new molecular autocatalytic reaction scheme based on a $\mathrm{H}_{2} \mathrm{O}_{2}$-mediated deprotection of a boronate ester probe into a redox cycling compound, generating an exponential signal gain in the presence of $\mathrm{O}_{2}$ and a reducing agent or enzyme. For such a purpose, new chemosensing probes built around a naphthoquinone/naphthohydroquinone redox-active core, masked by a self-immolative boronic ester protecting group, were designed. With these probes, typical autocatalytic kinetic traces with characteristic lags and exponential phases were obtained using either a UV-visible or fluorescence optical detection, or also using an electrochemical monitoring. Detection of concentrations as low as $0.5 \mu \mathrm{M} \mathrm{H} \mathrm{H}_{2}$ and $0.5 \mathrm{nM}$ of a naphthoquinone derivative were achieved in a relatively short time $(<1 \mathrm{hr})$. From kinetic analysis of the two cross-activated catalytic loops associated to the autocatalysis, the key parameters governing the autocatalytic reaction network were determined, indirectly showing that the analytical performances are currently limited by the slow nonspecific self-deprotection of boronate probes. Collectively, the present results demonstrate the potential of this new exponential molecular amplification strategy, which, due to its generic nature and modularity, is quite promising for coupling to a wide range of bioassays involving $\mathrm{H}_{2} \mathrm{O}_{2}$ or redox cycling compounds, or for being used as a new building block in the development of more complex chemical reaction networks.
\end{abstract}

\section{Introduction}

Molecular and biomolecular amplifications are of upmost importance in the transduction of (bio)chemical events into sensitive output signals, with many implications in areas ranging from cell signaling ${ }^{1}$ to in vitro diagnostic. ${ }^{2,3}$ Among the wide variety of molecular amplification schemes, those based on nonlinear signal-gain are undeniably the most powerful in terms of sensitivity and dynamic range. An emblematic example is the exponential molecular amplification of nucleic acids by PCR, a technique that was proven decisive in achieving the ultimate specific quantification of a few target nucleic acid sequences in a few tens of microliters. ${ }^{4} 5$ Generally speaking, exponential

[a] J. Pallu, Dr. C. Rabin, G. Creste, Dr. M. Branca, Dr. F. Mavré, Dr. B. Limoges

Laboratoire d'Electrochimie Moléculaire, UMR 7591 CNRS

Université Paris Diderot, Sorbonne Paris Cité

15, rue Jean-Antoine de Baïf, F-75205 Paris Cedex 13, France

E-mail: limoges@univ-paris-diderot.fr ; francois.mavre@univ-parisdiderot.fr ; mathieu.branca@univ-paris-diderot.fr

The supporting information is available online. amplifications originate from autocatalytic reaction schemes in which one of the products catalyzes its own formation, ${ }^{6}$ a process that is facilitated with nucleic acids thanks to the rich panoply of biological reagents (e.g., polymerases, nucleases, ...) available to selectively replicate DNA or RNA, ${ }^{4,5,7}$ or even self-replicate RNA through cleverly designed aptazyme. ${ }^{8}$ However, the autocatalytic concept of target replication or selfreplication is much challenging to transpose to non-nucleic acid such as proteins or small organic molecules. ${ }^{9}$ This is particularly true for proteins, even though the trypsinogen to trypsin conversion may be considered as a self-replicative process. ${ }^{10}$ For small organic molecules, apart from the enzyme-based ATP/ADP self-amplifying substrate cycle ${ }^{11,12}$ self-replication has only been recently demonstrated through the emergence of a range of new molecular-based autocatalytic concepts such as the dendritic chain reactions, ${ }^{13-19}$ self-propagating thiolatedisulfide exchanges, ${ }^{20,21}$ activation of a supramolecular allosteric catalyst, ${ }^{22}$ or photoinduced amplification of a radical chain reaction. ${ }^{23}$ These different strategies have been established for the detection of small analytes such as fluoride ${ }^{16,18,19}$ or chloride anions, ${ }^{22}$ thiols, ${ }^{14,20,21}$ or $\mathrm{H}_{2} \mathrm{O}_{2} \cdot{ }^{13,15,17,23}$ Among these small analytes, hydrogen peroxide is of particular interest because it plays an important role in a variety of biological processes or diseases, such as cell signaling, immune response, circadian redox oscillations, Alzheimer diseases, and cancer. ${ }^{24,}{ }^{25}$ Building new signal amplification systems based on a $\mathrm{H}_{2} \mathrm{O}_{2}$-triggered autocatalytic reaction is therefore of great interest not only for analytical purposes, but also to better understand some biological processes and to develop new molecular information processing systems for synthetic biology. ${ }^{10,12,20,26,27}$

Herein, we describe a new molecular-based autocatalytic reaction network (or autocatalytic set ${ }^{28}$ ) that leads to the sensitive detection of $\mathrm{H}_{2} \mathrm{O}_{2}$ through an exponential signal gain engendered by a $\mathrm{H}_{2} \mathrm{O}_{2}$-mediated autocatalytic deprotection of a chemosensitive probe (pro-RCC) into a redox cycling compound (RCC), as depicted in Scheme 1A. The main originality of this reaction scheme is the coupling between two catalytic loops. A first one leading to the release of a strongly reducing redox cycling compound $\left(\mathrm{RCC}_{\mathrm{Red}}\right)$ from the reaction of $\mathrm{H}_{2} \mathrm{O}_{2}$ with the pro-RCC probe, which then undergoes autoxidation in the presence of dissolved $\mathrm{O}_{2}$ to give the oxidized form $\mathrm{RCC}_{\mathrm{Ox}}$ and $\mathrm{H}_{2} \mathrm{O}_{2}$, thereby closing a first catalytic loop (Loop 1) by further reacting with a new molecule of pro-RCC (Scheme 1C). A second one where $R_{C C}$ Red is regenerated from $R C C_{0 x}$ by the direct action of a reducing chemical agent (S) or indirectly through a reducing enzyme (Enz) able to catalyze the electron transfer between the substrate $S$ and $\mathrm{RCC}_{\mathrm{Ox}}$ (Scheme 1D). As long as $\mathrm{S}$ and $\mathrm{O}_{2}$ are present in solution, $\mathrm{H}_{2} \mathrm{O}_{2}$ is uninterruptedly produced by this second catalytic loop (Loop 2). 
A

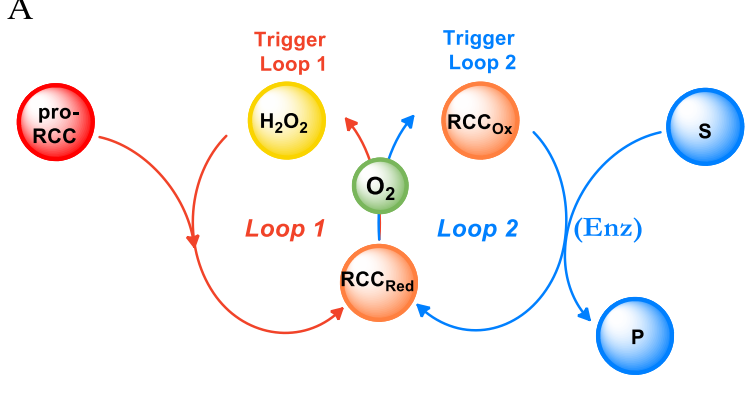

C

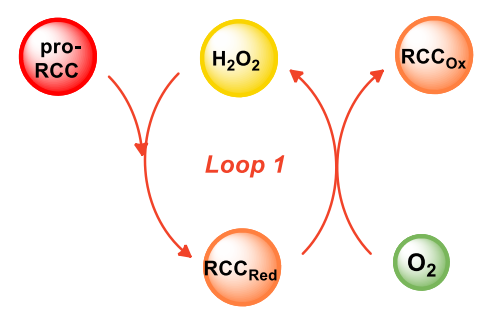

B

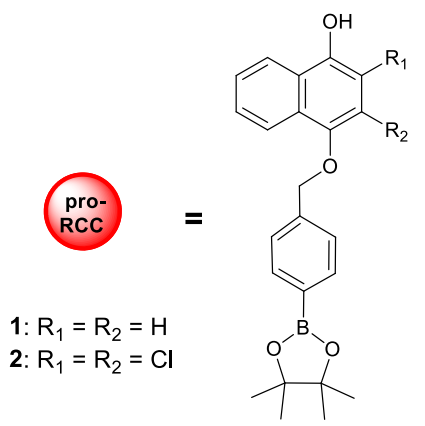

$\mathrm{D}$

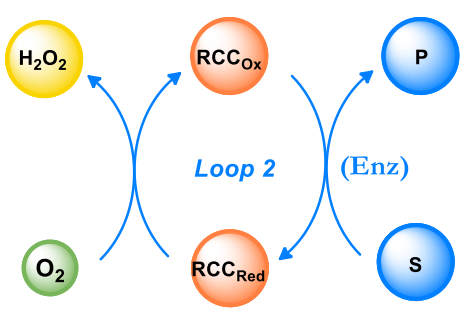

Scheme 1. (A) Principle of the $\mathrm{H}_{2} \mathrm{O}_{2}$-mediated autocatalytic deprotection of pro-RCC to RCC in the presence of $\mathrm{O}_{2}$ and a reducing substrate $\mathrm{S}$, the reaction with $\mathrm{S}$

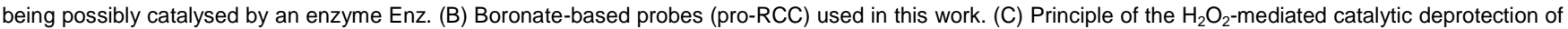
pro-RCC to RCC. (D) Principle of the redox cycling of RCC.

The whole process (Scheme $1 \mathrm{~A})$, depending on the relative rates of the two loops, can then produce an overstoichiometric quantity of $\mathrm{H}_{2} \mathrm{O}_{2}$ from a single deprotection event, which is equivalent to the following global reaction:

$$
\mathrm{H}_{2} \mathrm{O}_{2} \stackrel{k}{\longrightarrow} n \mathrm{H}_{2} \mathrm{O}_{2}
$$

that becomes naturally autocatalytic when $n>1$.

Alternatively, the proposed autocatalytic reaction network can be viewed as two interconnected catalytic loops that mutually activate (or catalyze) each other, wherein Loop 1 relies on $\mathrm{H}_{2} \mathrm{O}_{2}$ as a catalyst and produces RCC, while Loop 2 relies on $\mathrm{RCC}$ as a redox catalyst and produces $\mathrm{H}_{2} \mathrm{O}_{2}$. The symmetric nature of the reaction scheme therefore implies that this process can be indifferently triggered by any of the cycling partners (i.e., $\mathrm{H}_{2} \mathrm{O}_{2}$ or $\mathrm{RCC}$ ). Once started, the reaction is expected to generate with time an exponential accumulation of both $\mathrm{H}_{2} \mathrm{O}_{2}$ and RCC (as well as $\mathrm{P}$ ) until pro-RCC and/or $\mathrm{S}$ or $\mathrm{O}_{2}$ are eventually fully consumed. This novel strategy conceptually differs from the dendritic chain reactions previously reported, ${ }^{13-18}$ since it does not require the design of a dendritic probe functionalized by multiple self-immolative protecting groups, the latter of which is often synthetically challenging. In the present work, the use of rationally designed pro-RCCs (Scheme 1B) in an either allmolecular or enzyme-aided format proves the relevance of this conceptually new molecular amplification strategy, as well as its versatility in assays involving either detection of $\mathrm{H}_{2} \mathrm{O}_{2}$ or screening/detection of molecular compounds with redox cycling abilities.

\section{Results and Discussion}

\section{Design of the autocatalytic set}

To demonstrate the feasibility of our approach, we first had to consider the following criteria in the design of the autocatalytic set: $(i)$ to select an appropriate protection strategy of the RCC compound in order to obtain a pro-RCC probe capable to rapidly and selectively deprotect in the presence of $\mathrm{H}_{2} \mathrm{O}_{2}$ and, at the same time, to ensure an efficient masking of the $\mathrm{RCC}$ redox activity, (ii) to identify a RCC with good redox cycling abilities (i.e., by choosing a redox-active compound able to reversibly and rapidly cycle in the presence of a reducing agent and dissolved $\mathrm{O}_{2}$ ), (iii) to use a reducing chemical agent having a sufficiently strong reducing power towards the electron acceptor $\mathrm{RCC}_{\mathrm{Ox}}$ and no cross-reactivity with $\mathrm{O}_{2}$, or, in the case of an enzyme catalyzed reduction, to take advantage of an oxidoreductase able to efficiently and selectively reduce $\mathrm{RCC}_{\mathrm{Ox}}$ but unable to generate $\mathrm{O}_{2}{ }^{-}$or $\mathrm{H}_{2} \mathrm{O}_{2}$ from $\mathrm{O}_{2}$, and last (iv) to find reaction conditions that ensure a good chemical stability and favorable reactivity of the assorted partners and intermediates.

Oxidative deprotection of aromatic boronates by $\mathrm{H}_{2} \mathrm{O}_{2}$ is a wellknown biorthogonal reaction to generate phenols, ${ }^{29}$ which, thanks to its good chemoselectivity and capacity to operate efficiently under mild or near-neutral aqueous media (either directly $^{30}$ or indirectly through self-immolative spacers ${ }^{18,31,32}$ ), has been demonstrated as a reaction of choice in the design of a myriad of boronic acid- or boronic ester-based $\mathrm{H}_{2} \mathrm{O}_{2}$ chemosensing probes. ${ }^{30,33-36}$

From there, the next criterion is to select a suitable RCC with effective redox cycling properties. We thus postulated that redox cyclers bearing a quinone center belonging to the family of naphthoquinones (NQs) would be particularly suitable since they were shown to readily redox cycle in the presence of $\mathrm{O}_{2}$ and a reductant ${ }^{37}$ or a reductase, ${ }^{38,39}$ a property at the origin of their wide utilization as potent therapeutic cytotoxic agents. ${ }^{40,41,42}$ Indeed, their reduction potential is sufficiently low relative to benzoquinones to normally ensure fast autoxidation by molecular oxygen, ${ }^{43}, 44,45$ and high enough compared to anthraquinones to undergo efficient chemical or enzymatic reduction.

Having in mind the use of naphthoquinones as RCCs, we looked for chemical and enzyme reducing agents that would efficiently 
react with the 1,4-naphthoquinone (1,4-NQ). Ascorbate has been first considered as a chemical reducing agent. ${ }^{37,}$,6-48 Alternatively, the thermostable FMN-dependent diaphorase (DI) from the Bacillus stearothermophilus (EC 1.6.99.-) has been envisioned as a reducing enzyme thanks to its ability to efficiently catalyze the reduction of a wide range of NQs by $\mathrm{NADH}$. Interestingly, a rate constant as high as $10^{9} \mathrm{M}^{-1} \mathrm{~s}^{-1}$ has been reported for the reduction of menadione by $\mathrm{DI}$ at $\mathrm{pH} 8.5,{ }^{49}$ emphasizing the high reducing rate of this enzyme towards NQs. A further advantage of $\mathrm{DI}$ is its absence of cross-reactivity with $\mathrm{O}_{2 .}{ }^{49}, 50$ As an additional reducing enzyme, we have also considered the pyrroloquinoline quinone-dependent glucose dehydrogenase (PQQ-GDH) because of its high catalytic activity towards glucose oxidation and concomitant reduction of a broad range of quinones, ${ }^{51}$ and, as for $\mathrm{DI}$, an absence of reactivity with $\mathrm{O}_{2}$.

Finally, a slightly alkaline $0.1 \mathrm{M}$ Tris buffer of $\mathrm{pH} 8.5$ was chosen because the oxidative deprotection of arylboronates by $\mathrm{H}_{2} \mathrm{O}_{2}$ and autoxidation of $\mathrm{RCC}_{\text {red }}$ by $\mathrm{O}_{2}$ are both faster at higher $\mathrm{pHs}$ (the nucleophile $\mathrm{HO}_{2}^{-}$being the reactant involved in the chemoselective deprotection of arylboronates, ${ }^{29,52}$ and the doubly deprotonated hydroquinone being the more reactive form for $\mathrm{O}_{2}$ reduction owing to a higher driving force ${ }^{44}$ ). Moreover, this buffer and $\mathrm{pH}$ value were previously shown optimal for the catalytic reduction of a wide range of electron acceptors by $\mathrm{DI}$ in the presence of $\mathrm{NADH} .{ }^{49,50}$ Besides, EDTA was added to the reaction solution to scavenge and prevent any deleterious effects of adventitious traces of heavy metal cations, the latter being known to catalyze the oxidation of $\mathrm{NQH}_{2} \mathrm{~S}$ by $\mathrm{O}_{2}$ and to produce reactive oxygen species. ${ }^{53,54}$

The first pro-RCC compound we have investigated is the probe 1 (pro- $\mathrm{NQH}_{2}$ ) shown in Schemes $1 \mathrm{~B}$ and 2 (see Experimental Section for chemical synthesis), wherein an aromatic boronate protecting group has been installed, via a self-immolating spacer, in place of one of the hydroxyl group of the 1,4naphthohydroquinone. Oxidative cleavage of the boronic ester group in 1 by $\mathrm{H}_{2} \mathrm{O}_{2}$ is thus assumed to produce an intermediate that rapidly self-immolate (through a 1,6-elimination) into the desired 1,4- $\mathrm{NQH}_{2}$, which in the presence of $\mathrm{O}_{2}$ then leads to 1,4$\mathrm{NQ}$ and $\mathrm{H}_{2} \mathrm{O}_{2}$ (Scheme 2). Under the selected conditions, probe 1 was found relatively stable in solution (Figure S1), showing, after fast hydrolysis of the pinacol ester (leading to a small drop in absorbance during the first 10 minutes), ${ }^{55}$ no significant absorbance change over at least 2 hrs incubation in the Tris buffer. Moreover and as expected, after adding one equivalent of $\mathrm{H}_{2} \mathrm{O}_{2}$, probe 1 is fully converted into 1,4-NQ in less than 2 hrs (Figure S1). More interestingly, substoichiometric ratios of $\mathrm{H}_{2} \mathrm{O}_{2}$ can fully convert 1 into $1,4-\mathrm{NQ}$ (Figure S2), highlighting the catalytic nature of $\mathrm{H}_{2} \mathrm{O}_{2}$ in the chemical transformation of compound 1. This behavior strongly supports the mechanism of Loop 1 in Scheme 2. These results also show that probe 1 is an a priori worthy candidate to explore the proposed concept of exponential molecular amplification.

Separately, we have checked whether the stability of the generated 1,4-NQ in solution is satisfying or not. Figure S1 show that the UV-vis spectra of a freshly prepared Tris buffer solution of 1,4-NQ evolves very slowly with time into a new one (as attested by the isobestic points at $\lambda=236 \mathrm{~nm}, 262 \mathrm{~nm}, 325 \mathrm{~nm}$ and $361 \mathrm{~nm}$ ), a transformation that appears only marginally accelerated in the presence of $\mathrm{H}_{2} \mathrm{O}_{2}$.
In order to determine the deprotection rate of $\mathbf{1}$ by $\mathrm{H}_{2} \mathrm{O}_{2}$ we have followed the reaction by fluorescence (the boronic probe 1 exhibiting a marked fluorescence at $465 \mathrm{~nm}$ in contrast to 1,4$\mathrm{NQH}_{2}$ or $1,4-\mathrm{NQ}$ which do not fluoresce - see Figure S3A). The time-course decreases of fluorescence emitted by probe $\mathbf{1}$ as a function of different concentrations of $\mathrm{H}_{2} \mathrm{O}_{2}$ are reported in Figure S3B. In agreement to the catalytic nature of Loop 1 all fluorescence kinetic traces converge to a value close to zero according to a monoexponential decay, indicating again complete transformation of probe 1 into $1,4-\mathrm{NQ}$, even for substoichiometric ratios of $\mathrm{H}_{2} \mathrm{O}_{2}$. Fitting the experimental curves with a single exponential function allowed extracting $k_{\text {obs }}$, which once plotted as a function of $\left[\mathrm{H}_{2} \mathrm{O}_{2}\right]$ leads to a linear relationship (Figure $\mathrm{S} 3 \mathrm{C}$ ) from which the second order deprotection rate constant $k_{1}$ could be determined. A value of $k_{1}=3 \pm 1 \mathrm{M}^{-1} \mathrm{~s}^{-1}$ was obtained which is close to the deprotection rate constant of $5 \pm 1$ $\mathrm{M}^{-1} \mathrm{~s}^{-1}$ that can also be recovered from analysis of the initial rates of absorbance increase in Figure S2 (corresponding thus in this case to an indirect evaluation of $k_{1}$ from the growth rate of 1,4$N Q$ ). This value is typically within the range of kinetic rate constants previously published for $\mathrm{H}_{2} \mathrm{O}_{2}$-mediated deprotection of arylboronic esters at neutral or slightly basic $\mathrm{pHs}$ (i.e., rate constants ranging from 0.07 to $\left.4 \mathrm{M}^{-1} \mathrm{~s}^{-1}\right){ }^{56-60}$

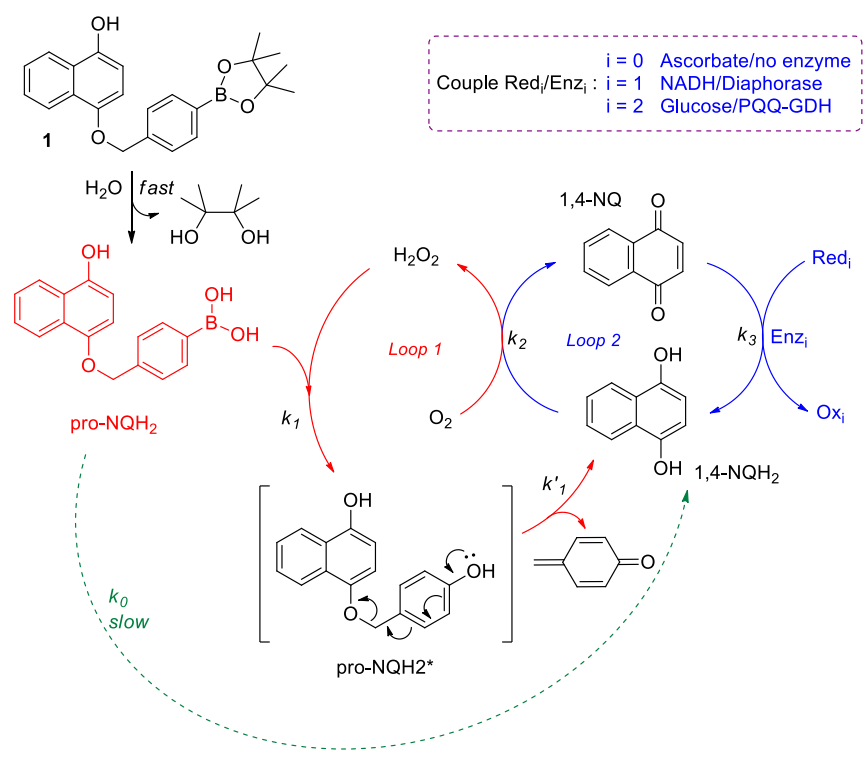

Scheme 2. Full autocatalytic reaction scheme involving probe 1 (the undesired nonspecific self-deprotection of 1 is also included - dashed arrow).

It is important to note that the $\mathrm{H}_{2} \mathrm{O}_{2}$-mediated deprotection of $\mathbf{1}$ is a two-step process wherein the second step of 1,6-elimination, if not fast, can be rate-limiting. ${ }^{31}$ The fact that in Figure S3B the overall curves fit well to a monoexponential decay and also that in Figure S3C there is a perfect linear relationship between $k_{\text {obs }}$ and $\left[\mathrm{H}_{2} \mathrm{O}_{2}\right]$, even for substoichiometric $\left[\mathrm{H}_{2} \mathrm{O}_{2}\right] /[1]$ ratios, strongly supports a liberation rate of the spacer (i.e., $k_{1}^{\prime}$ ) that is never rate-determining under our conditions. This would also mean that $k_{1}^{\prime}$ is most likely $>0.001 \mathrm{~s}^{-1}$, a value which agrees with that reported for analogous self-immolative spacers. ${ }^{31,61}$ The two other assumptions we have implicitly made for the determination of $k_{1}$ is that the autoxidation rate of $1,4-\mathrm{NQH}_{2}$ by $\mathrm{O}_{2}$ is fast relative to the other reaction steps in Loop 1 and it leads to a 
stoichiometric production of $\mathrm{H}_{2} \mathrm{O}_{2}$, which is reasonable given what has been reported in a previous study of the 1,4- $\mathrm{NQH}_{2}$ autoxidation at neutral $\mathrm{pH} .{ }^{45}$ In order to determine how fast is the autoxidation of 1,4-NQH $\mathrm{NQn}_{2}$ under our experimental conditions, we performed cyclic voltammetric experiments under redoxmediated catalysis (Figure S4). From analysis of the electrocatalytic current response, an apparent rate constant of $k_{2}$ $=3300 \pm 300 \mathrm{M}^{-1} \mathrm{~s}^{-1}$ was determined. This value confirms that, whatever the experimental conditions, the oxidation rate of 1,4$\mathrm{NQH}_{2}$ by $\mathrm{O}_{2}$ is fast enough to be none rate-limiting in Loop 1 . Another interesting information we can recover from experiments in Figure $\mathrm{S} 3$ is the slow self-deprotection rate of 1 in the absence of $\mathrm{H}_{2} \mathrm{O}_{2}$, an undesired process which is assumed to lead to the nonspecific release of 1,4-NQ but also possibly to the less problematic release of the boronic group by protodeboronation. ${ }^{62,63}$ An apparent first-order rate constant of 4 $\times 10^{-5} \mathrm{~s}^{-1}$ was deduced.

Finally, taking into account the overall rate constants which characterize the catalytic mechanism of Loop 1 (i.e., $k_{1}, k_{1}, k_{2}$, $k_{0}$ ), we were able from numerical simulations of kinetics to reproduce quite well the experimental UV-Vis kinetic traces characterizing the growth rate of 1,4-NQ from deprotection of probe 1 (Figure S5), a result which finally allows for a rational quantitative prediction of Loop 1. From an analytical point of view, probe 1 can be directly used to reveal the presence of the catalyst/trigger of Loop 1, i.e. $\mathrm{H}_{2} \mathrm{O}_{2}$. To assess the ability of probe 1 to sensitively detect $\mathrm{H}_{2} \mathrm{O}_{2}$ under the catalytic conditions of Loop 1, the calibration curve of $\mathrm{H}_{2} \mathrm{O}_{2}$ was plotted by reporting the absorbance in Figure $\mathrm{S} 2$ for 1 hour reaction as a function of $\mathrm{H}_{2} \mathrm{O}_{2}$ concentration. From this calibration plot, an $\mathrm{H}_{2} \mathrm{O}_{2}$ detection limit of $1.5 \mu \mathrm{M}$ can be estimated.

\section{Triggering the autocatalytic reaction with $\mathrm{H}_{2} \mathrm{O}_{2}$}

Switching from a catalytic (Loop 1) to an autocatalytic (Loop $1 \times$ Loop 2) reaction scheme requires only the addition of a reducing agent in solution. As explained in the introduction, the reduction of 1,4-NQ can be achieved either chemically (using ascorbate) or enzymatically (using diaphorase/NADH or PQQ-GDH/glucose as enzyme/substrate couples), two different strategies we have investigated.

\subsection{Autocatalytic set with ascorbate as reducing agent}

Ascorbate (Asc) was first tested as a chemical reducing agent of 1,4-NQ. The reaction between $1(50 \mu \mathrm{M})$ and different concentrations of $\mathrm{H}_{2} \mathrm{O}_{2}$ (ranging from 0 to $150 \mu \mathrm{M}$ ) has thus been characterized in the presence of an excess ascorbate $(0.5$ $\mathrm{mM})$. The kinetic measurements were achieved with a kinetic microplate reader for high throughput screening, wherein the reaction solutions (200 $\mu \mathrm{L}$ working volume) distributed in the microplate were left open to the air during the whole process. Figure $1 \mathrm{~A}$ shows a typical set of kinetics traces, the sigmoidal shapes of which are experimental evidences for an autocatalytic behavior. $^{6}$ The autocatalytic nature of these kinetics is also supported by the linearity (over more than one decade) found between the threshold time $t_{\mathrm{c}}$ (defined here as the time required to reach $50 \%$ of amplitude signal change) and the $\mathrm{H}_{2} \mathrm{O}_{2}$ concentration in a semi-logarithmic scale (Figure 1D). In the absence of $\mathrm{H}_{2} \mathrm{O}_{2}$, the prevalence of a nonspecifically triggered autocatalytic reaction severely restricts the detection limit of
$\mathrm{H}_{2} \mathrm{O}_{2}$ to the micromolar range (at lower concentrations all $t_{\mathrm{c}}$ values converge to a same limit of $\sim 31 \mathrm{~min}$ - see Figure 1D). Understanding the origin of this nonspecifically triggered response is therefore of crucial importance to improve the analytical performances of the method, an issue that is reminiscent of exponential molecular amplifications. ${ }^{64}$ It is likely that, in our case, the nonspecific response predominantly arises from the moderate stability of $\mathbf{1}$ that slowly self-deprotects in aqueous solution to cause the undesired leakage of $1,4-\mathrm{NQH}_{2}$ $\left(k_{0} \sim 10^{-5} \mathrm{~s}^{-1}\right)$. Another plausible contribution is the slow cross reactivity between $\mathrm{O}_{2}$ and Asc that can lead to the release of $\mathrm{O}_{2}{ }^{*-}$ and so indirectly to the slow production of $\mathrm{H}_{2} \mathrm{O}_{2}$ by either dismutation or cross-reactions with reducing species. ${ }^{65-67}$

With the aim to rationally predict the sigmoidal kinetic traces obtained in Figure $1 \mathrm{~A}$ and to better highlight the validity of the autocatalytic reaction mechanism postulated in Scheme 2, we completed our analysis of rate constants by an independent kinetics characterization of Loop 2. The time-course of this redox cycling reaction was monitored spectrophotometrically through the absorbance decrease of Asc at $262 \mathrm{~nm}$ as a function of different 1,4-NQ and Asc concentrations in an air-saturated Tris buffer $(\mathrm{pH}$ 8.5). From analysis of the experimental kinetic traces, a $k_{3}$ rate constant value of $170 \mathrm{M}^{-1} \mathrm{~s}^{-1}$ was estimated (see Supporting Information for details). Compared to the apparent autoxidation rate constant $k_{2}$ of $3300 \mathrm{M}^{-1} \mathrm{~s}^{-1}$ independently determined by cyclic voltammetry, the magnitude of $k_{3}$ here definitely establishes that the redox cycling process is under kinetic control of the reduction of 1,4-NQ by Asc.

An additional reaction that was necessary to evaluate as a control but also for its potential influence on the nonspecific response of the system is the autoxidation of ascorbate in an airsaturated buffer. Monitoring the UV-vis absorbance change of ascorbate solutions in Tris buffer $(p H$ 8.5) allowed us to demonstrate a slow zeroth order kinetics autoxidation of Asc (Figure S8), leading to an apparent first order autoxidation rate of $2 \times 10^{-5} \mathrm{~s}^{-1}$ (a value which is in line to those previously published $\left.{ }^{65,}{ }^{67}\right)$. Assuming that the $\mathrm{O}_{2}$ concentration remains constant (i.e., $0.25 \mathrm{mM}$ at $1 \mathrm{~atm}$ and $25^{\circ} \mathrm{C}$ ), a second order rate constant of $k_{0}^{\prime}=0.08 \mathrm{M}^{-1} \mathrm{~s}^{-1}$ could thus be estimated. This slow autoxidation of ascorbate does not mean it necessarily leads to a significant production of $\mathrm{H}_{2} \mathrm{O}_{2}$ and so to a large contribution to the nonspecific triggering of the autocatalytic process. In order to evaluate the degree to which this autoxidation may affect or not the nonspecific response, Asc solutions ( $0.5 \mathrm{mM}$ in Tris buffer) were allowed to age between $15 \mathrm{~min}$ and $3 \mathrm{hrs}$ before being tested with probe $\mathbf{1}$ in the presence or absence of one equivalent $\mathrm{H}_{2} \mathrm{O}_{2}$. The results we obtained (not shown) demonstrate that, regardless of the ageing time, the autocatalytic responses are identical to those recovered from a freshly prepared Asc solution, thus definitively eliminating the ascorbate autoxidation as a main source of nonspecific response.

Knowing the absolute values of all of the rate constants involved in Loop 1 and Loop 2, it was then interesting to numerically simulate the autocatalytic kinetics traces resulting from the combination of these two cross-activated catalytic loops (see Supporting Information for details). Remarkably, a quite good correspondence between the simulated and experimental kinetic traces was obtained using the following set of parameters: 
A

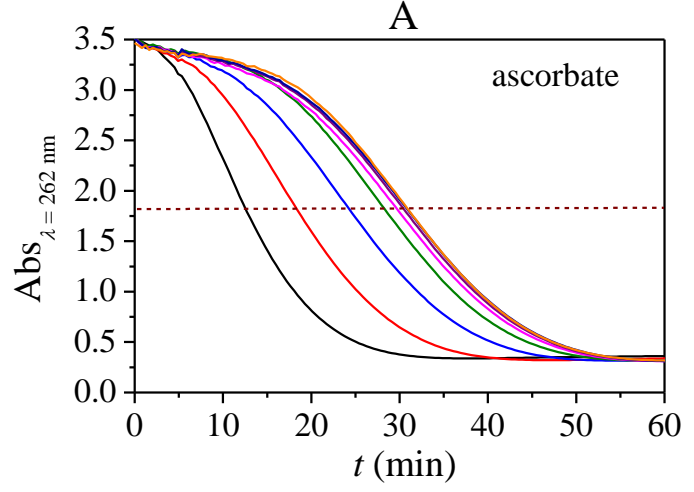

\section{$\mathrm{C}$}

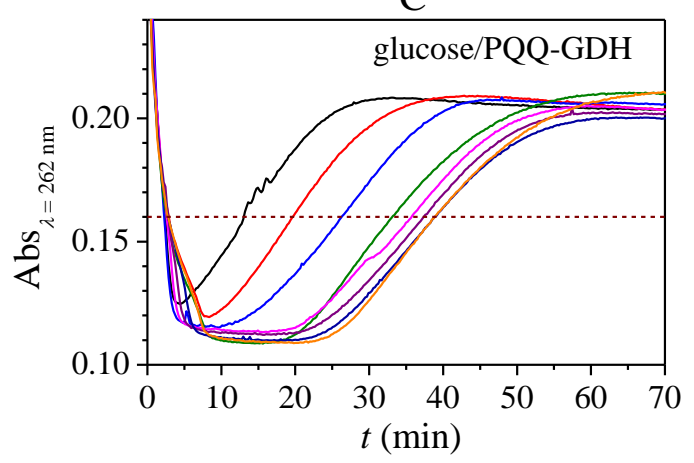

$\mathrm{B}$

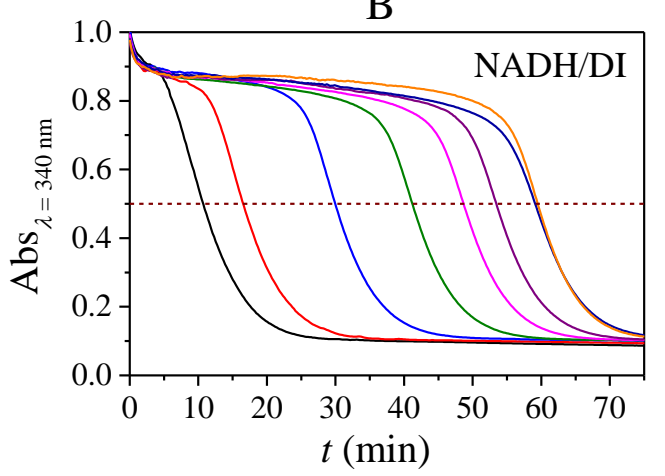

$\mathrm{D}$

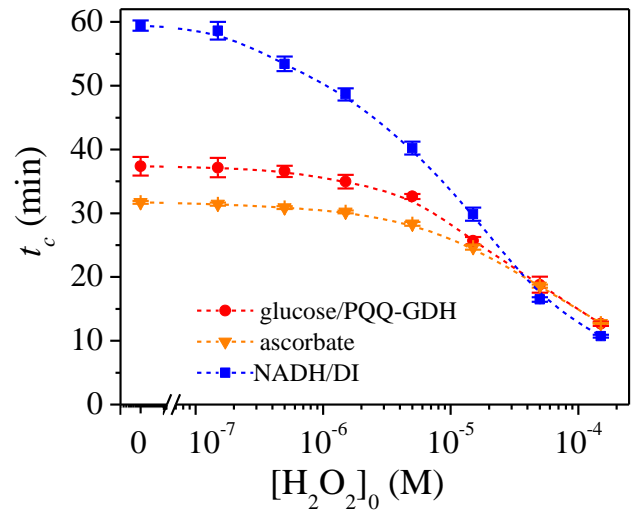

Figure 1. (A, B, C) UV-vis kinetic traces monitored at (A, C) $262 \mathrm{~nm}$ or (B) $340 \mathrm{~nm}$ in a 96 -wells microtiter plate during the reaction generated from the mixing of different concentrations of $\mathrm{H}_{2} \mathrm{O}_{2}$ (from left to right: $150,50,15,5,1.5,0.5,0.15$, and $0 \mu \mathrm{M}$ ) to solutions containing $50 \mu \mathrm{M} 1$ and either (A) $0.5 \mathrm{mM}$ Asc, (B) $10 \mathrm{nM}$ $\mathrm{DI}$ and $250 \mu \mathrm{M} \mathrm{NADH}$, or (C) $10 \mathrm{nM} \mathrm{PQQ-GDH}$ and $1 \mathrm{mM}$ glucose. All experiments were conducted in an air-saturated $0.1 \mathrm{M}$ Tris buffer ( $p H$ 8.5) containing 10 $\mu M$ EDTA. (D) Semi-logarithmic calibration curves obtained from the threshold times $\left(t_{c}\right)$ recovered from the crossing of the horizontal dashed line in A, B and $C$ to the kinetic traces ( $t_{c}$ is defined here as the time for which the absorbance is decrease approximatively half to the maximal absorbance change amplitude). Errors bars are standard deviations from triplicates.

$k_{1}=6 \mathrm{M}^{-1} \mathrm{~s}^{-1}, k_{1}^{\prime}=0.001 \mathrm{~s}^{-1}, k_{2}=3300 \mathrm{M}^{-1} \mathrm{~s}^{-1}, k_{0}=10^{-5} \mathrm{~s}^{-1}, k_{3}=$ $170 \mathrm{M}^{-1} \mathrm{~s}^{-1}$ and $k_{0}^{\prime}=0.08 \mathrm{M}^{-1} \mathrm{~s}^{-1}$ (Figure 2), a result which finally corroborates the proposed mechanism and confirms a nonspecific response mainly governed by the slow spontaneous self-deprotection of probe 1 to $\mathrm{NQH}_{2}$.

\subsection{Autocatalytic set with enzymatic reduction}

We next investigated the reaction of $1(50 \mu \mathrm{M})$ with $\mathrm{H}_{2} \mathrm{O}_{2}$ in the presence of $10 \mathrm{nM} \mathrm{DI}$ and $250 \mu \mathrm{M} \mathrm{NADH}$. The consumption of $\mathrm{NADH}$ was easily followed at $340 \mathrm{~nm}$ (Figure 1B). Again, sigmoidal kinetics traces are observed, showing well-defined lags and exponential phases. A good linearity is found between $t_{\mathrm{c}}$ and $\log \left(\left[\mathrm{H}_{2} \mathrm{O}_{2}\right]_{0}\right)$ over two decades from 1 to $100 \mu \mathrm{M}$ (Figure 1D). Compared to ascorbate, the detection of $\mathrm{H}_{2} \mathrm{O}_{2}$ was improved up to the submicromolar range (a LOD of $0.5 \mu \mathrm{M} \mathrm{H}_{2} \mathrm{O}_{2}$ can be estimated). Improvement of the detection limit mainly results from a nonspecific blank response delayed to longer times. More surprising is the somewhat lower analytical sensitivity compared with ascorbate (the linear part of the calibration curve in Figure 1D is indeed steeper for $\mathrm{NADH} /$ diaphorase than for Asc, demonstrating thus a slower response time for a given $\left[\mathrm{H}_{2} \mathrm{O}_{2}\right]_{0}$ concentration). This lower sensitivity is unexpected considering the higher reducing efficiency of the NADH/DI couple compared to ascorbate. As we will see later on, such an effect can be explained by an inhibition of the autoxidation of $1,4-\mathrm{NQH}_{2}$ by DI, leading thus to a slower production rate of $\mathrm{H}_{2} \mathrm{O}_{2}$ by redox cycling. For this system, besides the spontaneous self-deprotection of $\mathbf{1}$, the non-specific response may also originate from residual traces of $\mathrm{NADH}$ oxidase activity in DI (the DI supplier report an activity $<0.01$ wt. \%), or from NADH autoxidation even if the latter is very slow compared to Asc (which is attested by the excellent stability of a $\mathrm{NADH}$ solution in an air-saturated Tris buffer - Figure S8). ${ }^{68}$

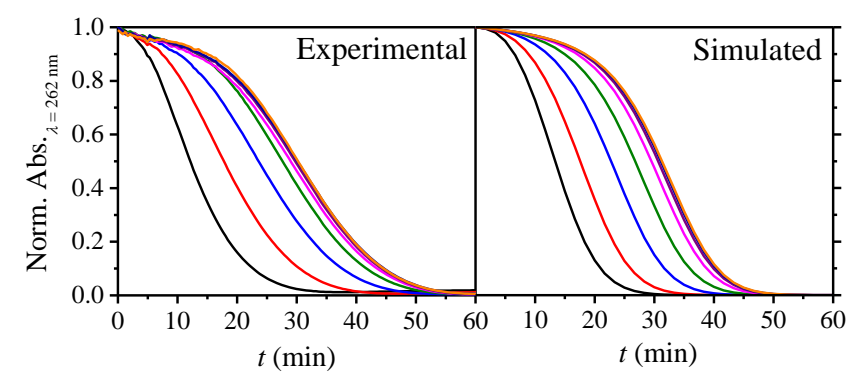

Figure 2. (Left) Same experimental absorbance kinetic traces than those reported in Figure $1 \mathrm{~A}$ but after normalization to the initial absorbance. The $\mathrm{H}_{2} \mathrm{O}_{2}$ concentrations are (from left to right): $150,50,15,5,1.5,0.5,0.15$ and 0 $\mu \mathrm{M}$. (Right) Theoretical normalized kinetic traces obtained from numerical simulation of the autocatalytic mechanism proposed in Scheme 2 and using the following set of rate constants: $k_{1}=6 \mathrm{M}^{-1} \mathrm{~s}^{-1}, k_{1}^{\prime}=0.001 \mathrm{~s}^{-1}, k_{2}=3300 \mathrm{M}^{-1} \mathrm{~s}$ ${ }^{1}, k_{0}=10^{-5} \mathrm{~s}^{-1}, k_{3}=170 \mathrm{M}^{-1} \mathrm{~s}^{-1}$ and $k_{0}^{\prime}=0.08 \mathrm{M}^{-1} \mathrm{~s}^{-1}$ (see Supporting Information for details). The color code is the same than on the left graph. 
In an attempt to disentangle these different possible contributions, we have investigated the effect of a pre-incubation period of $\mathbf{1}$ in the reaction buffer onto the nonspecific blank response generated under autocatalysis conditions. It is clear from the results in Figure S9 that a prolonged pre-incubation of 1 in the Tris buffer drastically shortens the lag phase associated to the nonspecific response, suggesting again a major contribution of the pro-RCC instability in this undesired process.

As suggested earlier, PQQ-GDH is also a good candidate to play the role of a reducing enzyme. However, glucose has the inconvenient to be UV-vis transparent contrary to ascorbate and $\mathrm{NADH}$. It led us to monitor the reaction progress either through the increase of the UV-vis absorbance at $262 \mathrm{~nm}$, a wavelength selective to the oxidized 1,4-NQ, or the decrease of the fluorescence of $\mathbf{1}$ at $465 \mathrm{~nm}$. Results in UV-vis are gathered in Figure $1 \mathrm{C}$ and those for fluorescence are reported in Figure $\mathrm{S} 10$ We may observe an exponential increase in absorbance change that is synchronized to the exponential decrease in fluorescent signal, witnessing an autocatalytic process wherein 1,4-NQ exponentially accumulates concomitantly with the consumption of pro-RCC. One may also observe that the analytical sensitivity with this alternative reducing enzyme is not significantly different from that of ascorbate (the linear part of the $\mathrm{H}_{2} \mathrm{O}_{2}$ calibration curves are almost overlaid in Figure 1D). Moreover, the dynamic range of the calibration curve is narrower than DI (less than two decades, ranging from ca. 5 to $100 \mu \mathrm{M}$ ), mainly restricted by the prevalence of a strong nonspecific response which reduces the LOD to $\sim 1 \mu \mathrm{M} \mathrm{H}_{2} \mathrm{O}_{2}$.

Improving the different rates of the autocatalytic set (e.g. by improving the rate constants of each of the two catalytic loops) is a way to improve the analytical performances of the system. On that regard, increasing the $\mathrm{pH}$ is supposed to have a positive role on both loops (simultaneously favoring the reactivity between the probe and $\mathrm{H}_{2} \mathrm{O}_{2}$ as well as the auto-oxidation of $\mathrm{RCC}_{\text {Red }}$ ). We thus performed the reaction at a slightly higher $\mathrm{pH}$ of 9.0 and as expected it had a positive impact on the kinetics of the reaction (as exemplified with probe $\mathbf{1}$ and $P Q Q-G D H$ in Figure $\mathrm{S} 10$, which shows a shift of $t_{\mathrm{c}}$ towards shorter response times). However no better performances could be reached, meaning that slightly higher $\mathrm{pH}$ also concomitantly affects the chemical stability of probe $\mathbf{1}$ and so the nonspecific response. Another possibility to tune the autocatalytic reaction kinetics is to adjust the enzyme concentration as this potentially alters the kinetics of Loop 2. In principle, lowering the concentration of the enzyme would decrease the regeneration rate of $R C C_{\text {Red }}$ and therefore would impact the required overstoichiometric production of $\mathrm{H}_{2} \mathrm{O}_{2}$ to reach an autocatalytic regime. Figures $\mathrm{S} 11$ and $\mathrm{S} 12$ clearly illustrate this effect on the non-specific autocatalytic response involving either DI or PQQ-GDH (enzyme concentrations were varied from $30 \mathrm{nM}$ to $30 \mathrm{pM}$ ). Indeed, at concentration lower than $1 \mathrm{nM}$ DI or $3 \mathrm{nM} P Q Q-G D H$, the lag phase tends to disappear and the abrupt exponential absorbance decrease is progressively converted to a linear decrease (which is typical of a redox cycling process ratecontrolled by a zeroth order autoxidation kinetics), meaning that the reaction enters a nearly linear kinetic regime for which the value of $n$ in eq. 1 is probably only slightly greater than 1 . Besides, for concentrations above $1 \mathrm{nM}$ DI or $3 \mathrm{nM} \mathrm{PQQ-GDH,}$ the higher the concentration, the steepest is the kinetic curve during its exponential phase. What is somehow surprising for these higher concentrations is the influence of the enzyme concentration on the duration of the lag phase, especially for DI. Counter-intuitively, the longer lag phase is observed for the highest enzyme concentration of $30 \mathrm{nM}$. This behavior witnesses an inhibitory effect of the enzyme at the early stage of the amplification, an inhibition that most likely slows down the autoxidation rate of $1,4-\mathrm{NQH}_{2}$ by $\mathrm{O}_{2}$. This inhibitory effect, particularly pronounced for $\mathrm{DI}$, may explain the unexpectedly lower sensitivity of the $\mathrm{H}_{2} \mathrm{O}_{2}$ calibration curve in Figure 1D when using $\mathrm{NADH} / \mathrm{DI}$ rather than ascorbate as a reducing agent. Further investigations are required to clarify this effect.

Independently of the optical detection methods, the autocatalytic process was also investigated using electrochemistry, taking advantage of the electroactivity of the released naphthoquinone. Indeed, the redox activity of 1,4-NQ can be recovered from the magnitude of the catalytic current response in cyclic voltammetry associated to the redox-mediated reduction of $\mathrm{O}_{2}$ (see Figure $\mathrm{S} 4$ and Figure $3 \mathrm{~A}$ below). To avoid the interference of $\mathrm{H}_{2} \mathrm{O}_{2}$ that is electrocatalytically generated during a cyclic voltammetric scan, the electrochemical measurement was performed outside of the reaction vessel by periodically sampling a few tens of microliters of the reaction mixture (using a miniaturized screen-printed electrochemical cell). The resulting kinetic plots obtained for a sample of $15 \mu \mathrm{M} \mathrm{H}_{2} \mathrm{O}_{2}$ and a negative control with no $\mathrm{H}_{2} \mathrm{O}_{2}$ are reported in Figure 3B. As expected, the data show an exponential growth of the electrochemical response, which arises at an earlier $t_{\mathrm{c}}$ value for the sample than for the negative control. This result is in good correlation with that obtained using an UV-vis detection mode (Figure 1B).
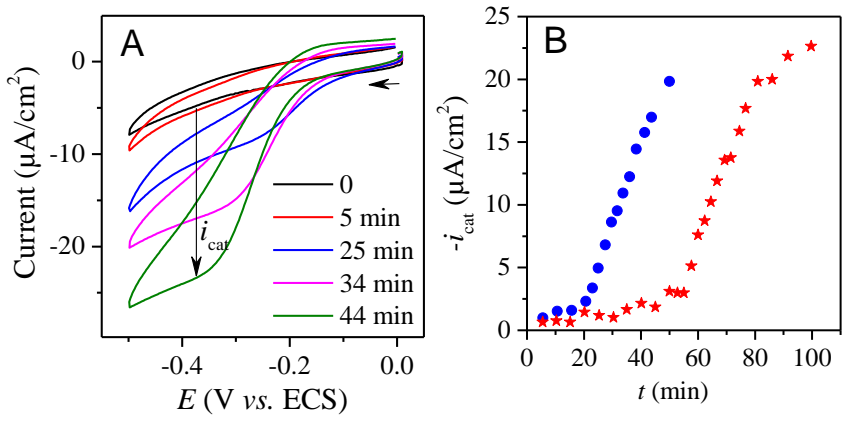

Figure 3. (A) Cyclic voltammetric responses of a solution mix containing 15 $\mu \mathrm{M} \mathrm{H}_{2} \mathrm{O}_{2}, 50 \mu \mathrm{M} 1,10 \mathrm{nM}$ DI and $250 \mu \mathrm{M} \mathrm{NADH}$, recorded at different reaction times (the time is reported on the graph). Scan rate: $50 \mathrm{mV} \cdot \mathrm{s}^{-1}$. (B) Autocatalytic kinetic traces obtained by reporting the sampled catalytic current responses in cyclic voltammetry as a function of the reaction time for a starting $\mathrm{H}_{2} \mathrm{O}_{2}$ concentration of (blue dots) $15 \mu \mathrm{M}$ and (red stars) $0 \mu \mathrm{M}$.

\section{Triggering the reaction with $\mathrm{RCC}$ through redox cycling-based $\mathrm{H}_{2} \mathrm{O}_{2}$ production}

A versatile function of this cross-catalytic reaction network lies in its capacity to be triggered not only by $\mathrm{H}_{2} \mathrm{O}_{2}$, but also by any $\mathrm{RCC}$ as illustrated by the reaction network depicted in Scheme 3 (the pro-RCC probe is here represented by the pro- $\mathrm{NQH}_{2}$ probe 1). This might be viewed as a drawback since any traces of RCC contaminating the pro-RCC probe would lead to an autocatalytic transformation of pro-RCC. However we can turn this as an advantage for the detection of RCC traces or more generally of any redox cycling compound that is a potent trigger of the system by producing $\mathrm{H}_{2} \mathrm{O}_{2}$.

\subsection{Screening the triggering capacity of different RCC}

By definition, any RCC in the presence of $\mathrm{O}_{2}$ and a well-chosen reducing agent can redox cycle and lead to the production of hydrogen peroxide. In the presence of our pro- $\mathrm{NQH}_{2}, \mathrm{H}_{2} \mathrm{O}_{2}$ 
produced can further react and trigger the above described autocatalytic process. This triggering capacity is also a mean to assess the ability of a RCC to efficiently produce $\mathrm{H}_{2} \mathrm{O}_{2}$ by redox cycling. It was thus investigated for a series of naphthoquinones (0.2 $\mu \mathrm{M}$ of each $\mathrm{NQ}$ was added to a solution containing substrate 1, DI and NADH). Note in that case the nature of the $\mathrm{NQ}$ trigger can be different from the 1,4-NQ released by deprotection of compound $\mathbf{1}$, and so the role of the NQ trigger is only to start the reaction, while this is the 1,4-NQ that exponentially accumulates over the long term.

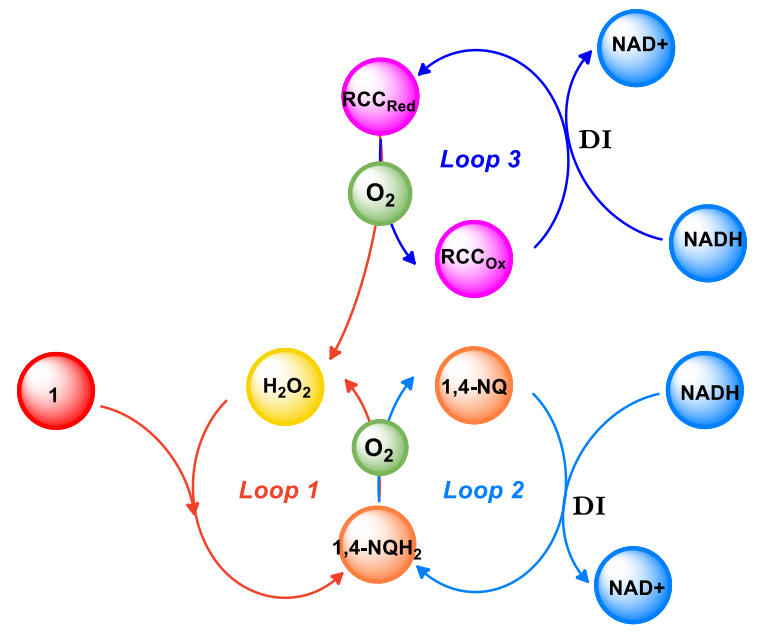

Scheme 3. Principle for the determination of the RCC triggering capacity using 1 as a pro- $\mathrm{NQH}_{2}$ probe.

As shown in Figure 4 (top), the different NQs induced an autocatalytic response that is faster than the blank recorded in the absence of $N Q$, evidencing their triggering capacity. The time response is also observed to vary significantly as a function of the nature of RCC. The 2-amino-3-chloro- and 2,3-dichloronaphthoquinones provoked the fastest responses $\left(t_{c} \sim 12-13\right.$ $\mathrm{min}$ ), suggesting that they are more amenable to redox-cycle rapidly and so to produce more $\mathrm{H}_{2} \mathrm{O}_{2}$ in a shorter time. For these two molecules, redox cycling is so efficient that, during the lag phase, $\mathrm{NADH}$ is well discernably linearly consumed (during the first 5-7 minutes of the reaction) before the autocatalytic process becomes kinetically significant and takes over. NQs can be ranked according to their ability to redox-cycle more or less rapidly, which under our experimental conditions (here in the presence of $\mathrm{DI}$ ) leads to the following ranking (from faster to slower): 2-amino-3-chloro-1,4-NQ $\approx 2,3$-dichloro-1,4-NQ > 2methoxy-1,4-NQ > 1,4-NQ $\approx 2$-hydroxy-1,4-NQ > 1,2-NQ > menadione. These results highlight the versatility and potentiality of our approach since it can be used as a time-readout-based method for the screening of redox cycling properties of any compound. ${ }^{69-71}$ In order to see if there is a linear free-energy relationship between the triggering properties of NQs and their reduction potential, the $t_{c}$ value of each $N Q$ has been reported on the bottom graph of Figure 4 as a function of the apparent midpoint potential of $\mathrm{NQs}\left(E_{1 / 2}\right.$, independently determined by cyclic voltammetry at $p \mathrm{H} 8.5$ in the absence of $\mathrm{O}_{2}$ ). If we assumed that, in the presence of $\mathrm{NADH} / \mathrm{DI}$, the autoxidation of $\mathrm{NQ}$ by $\mathrm{O}_{2}$ is the rate-limiting step of Loop 2, one should thus expect that the lower the $E_{1 / 2}$ of the $\mathrm{NQ} / \mathrm{NQH}_{2}$ couple (or more rigorously the lower is the reducing potential of the $\mathrm{NQ}^{*} / \mathrm{NQH}_{2}$
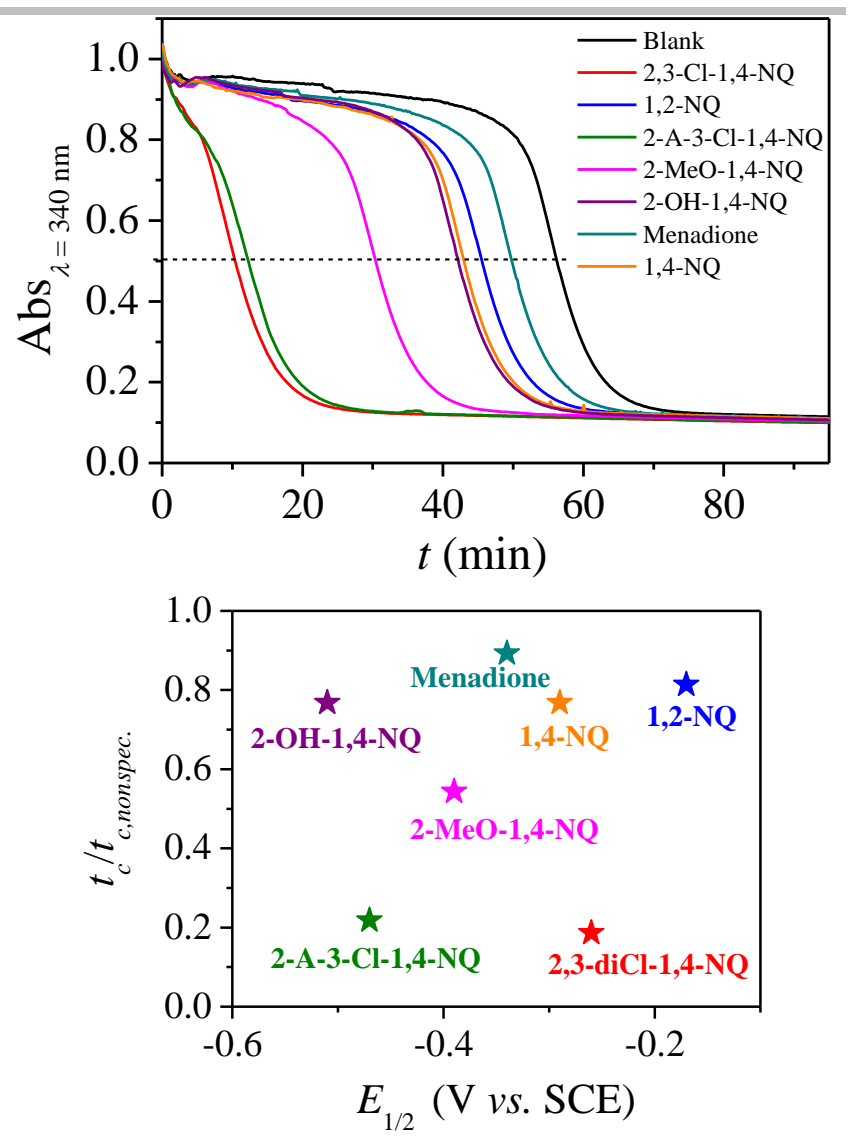

Figure 4. (Top) UV-vis kinetic traces recorded at $340 \mathrm{~nm}$ (monitoring of $\mathrm{NADH}$ consumption) in a 96-wells microtiter plate. Experiments were performed in an air-saturated $0.1 \mathrm{M}$ Tris buffer $(p \mathrm{H}$ 8.5) containing $10 \mu \mathrm{M}$ EDTA, $50 \mu \mathrm{M} 1,10$ $\mathrm{nM} \mathrm{DI}, 250 \mu \mathrm{M} \mathrm{NADH}$, and $0.2 \mu \mathrm{M}$ of (orange) 1,4-NQ, (olive) 2-amino-3chloro-1,4-NQ, (red) 2,3-dichloro-1,4-NQ, (blue) 1,2-NQ, (magenta) 2methoxy-1,4-NQ, (purple) 2-hydroxy-1,4-NQ, (cyan) menadione, and (black) no quinone. (Bottom) Threshold time (normalized to the nonspecific one obtained from the blank) vs. apparent midpoint potential of NQs.

couple relative to the reducing potential of $\mathrm{O}_{2} / \mathrm{O}_{2}{ }^{-43}$ ), the faster the autoxidation reaction with $\mathrm{O}_{2}$ to produce $\mathrm{H}_{2} \mathrm{O}_{2}$. The graph however shows that there is no obvious trend from the plot, showing for instance with the 2,3-dichloro-1,4-NQ an impressively fast response while its reducing potential is among the highest of NQs. This behavior reflects a more complex reality of the reduced naphthoquinones reactivity towards molecular oxygen ${ }^{43}$ and also probably towards diaphorase. More important is the fact that 2,3-dichloro-1,4-NQ is the best hit from this screening experiment, allowing us to further consider it for the design of an improved pro-RCC probe (vide infra).

\subsection{Direct detection of RCC}

In order to evaluate the lowest concentration of RCC leading to a distinct autocatalytic kinetic trace from the nonspecific one, 2,3-dichloro-1,4-NQ was tested as a trigger over a range of concentrations from $0.5 \mathrm{nM}$ to $1.5 \mu \mathrm{M}$ in the presence of $1, \mathrm{DI}$ and NADH. As shown in Figure 5, the lower the concentration of 2,3-dichloro-1,4-NQ, the longer is the time required to observe the autocatalytic response. The $t_{c}$ values for concentrations below $50 \mathrm{nM}$ follow an approximately linear relationship with the log scale of the initial $\mathrm{RCC}_{\mathrm{Ox}}$ concentration (bottom graph in Figure 5), and then tends to deviate from linearity at higher concentrations before reaching a kinetic regime no longer controlled by autocatalysis but simply by the catalytic Loop 1 . 

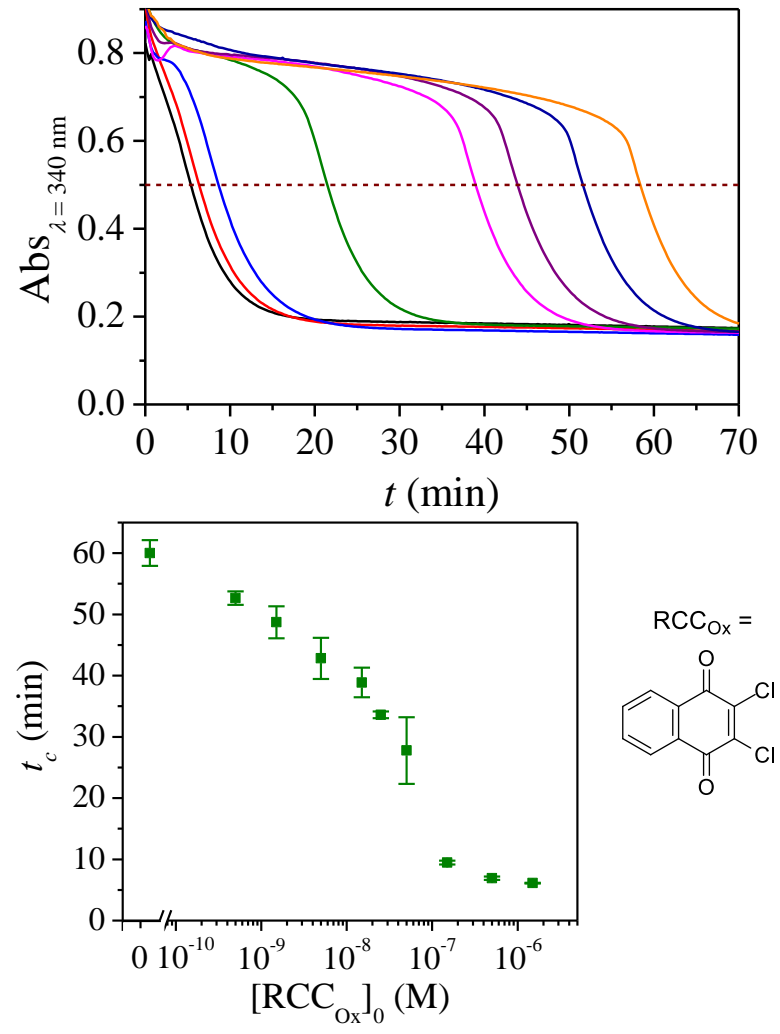

Figure 5. (Top) UV-vis kinetic traces recorded at $340 \mathrm{~nm}$ (monitoring of NADH consumption) in a 96-wells microtiter plate. All experiments were conducted in an air-saturated $0.1 \mathrm{M}$ Tris buffer $(\mathrm{pH} 8.5)$ containing $10 \mu \mathrm{M}$ EDTA, $50 \mu \mathrm{M} 1$, $10 \mathrm{nM} \mathrm{DI}, 250 \mu \mathrm{M} \mathrm{NADH}$ and the following decreasing concentrations of 2,3dichloro-1,4-NQ (from left to right): $1500,500,150,50,15,5,1.5$, and $0 \mathrm{nM}$. (Bottom) Semi-logarithmic calibration plot obtained by reporting the threshold time recovered from the crossing horizontal dashed line in $\mathrm{A}$ as a function of 2,3-dichloro-1,4-NQ concentration. Errors bars correspond to standard deviations from triplicates.

This loss of linearity suggests again some mechanistic complications which probably arise from competition reactions between the different radical intermediates generated by the system. Overall, subnanomolar concentrations of 2,3-dichloro1,4-NQ are easily detected with this method, a performance that could not be reached through an only redox cycling molecular amplification. Any event that could produce low amounts of this RCC would therefore potentially be sensitively detected through this approach. ${ }^{15}$ This performance also advocates the use of this compound in the design of an improved ester boronic substrate.

\subsection{Design of a new pro-RCC}

Improving the different rate constants of the autocatalytic set could help to improve the response of the system either by shortening the assay time required for the detection of the targeted $\mathrm{H}_{2} \mathrm{O}_{2}$ or $\mathrm{RCC}$ molecules, or by improving the discrimination between the specific and nonspecific autocatalytic responses. For such purpose, we have examined the possibility to tune the reaction rates of the redox cycle (Loop 2) by selecting a better redox cycler to design the probe. In particular, we postulated that it would be advantageous to substitute the masked 1,4-NQ in probe 1 by a 2,3-dichloro-1,4-NQ. We therefore synthesized probe 2 (Scheme 1B, see Experimental Section for chemical synthesis). In the absence of $\mathrm{H}_{2} \mathrm{O}_{2}, 2$ undergoes a first rapid hydrolysis of its pinacol ester followed by a slow and relatively negligible nonspecific self-deprotection over several hours (Figure S13, A and E), which is very analogous to that obtained with probe 1. This pro-RCC also readily reacts in the presence of one equivalent $\mathrm{H}_{2} \mathrm{O}_{2}$ (Figure $\mathrm{S} 13, \mathrm{C}$ and $\mathrm{E})$ at a deprotection rate that is similar to probe $\mathbf{1}$. The substituted naphthoquinone also evolves slowly in the buffer either in the presence or absence of one equivalent $\mathrm{H}_{2} \mathrm{O}_{2}$ (Figure $\mathrm{S} 13, \mathrm{~B}, \mathrm{D}$ and $\mathrm{F}$ ), but the time scale over which these transformations occur remains slow. Reaction of this new probe with $\mathrm{H}_{2} \mathrm{O}_{2}$ in the presence of $\mathrm{NADH} / \mathrm{DI}$ led to the autocatalytic kinetic curves shown in Figure 6. As expected, complete $\mathrm{NADH}$ consumption occurs in a much shorter time than probe 1, indicating an effectively accelerated autocatalytic reaction that results in an improved analytical sensitivity. Corollary, this faster kinetics is also associated with a non-specific autocatalytic response that arises earlier than previously. Consequently, even though the response time is $\sim 4$-fold shortened with probe 2 , only concentrations over the micromolar range are clearly discernible from the blank response, which in terms of limit of detection is finally worse than with probe 1 . These results show that accelerating the kinetics of Loop 2 is well adapted to shorten the autocatalytic responses but unfortunately is not necessarily appropriate to improve the detection limit. Such behavior can be easily rationalized by the fact that the non-specific response resulting from the leakage of 1,4-NQ in Loop 1 (i.e., related the
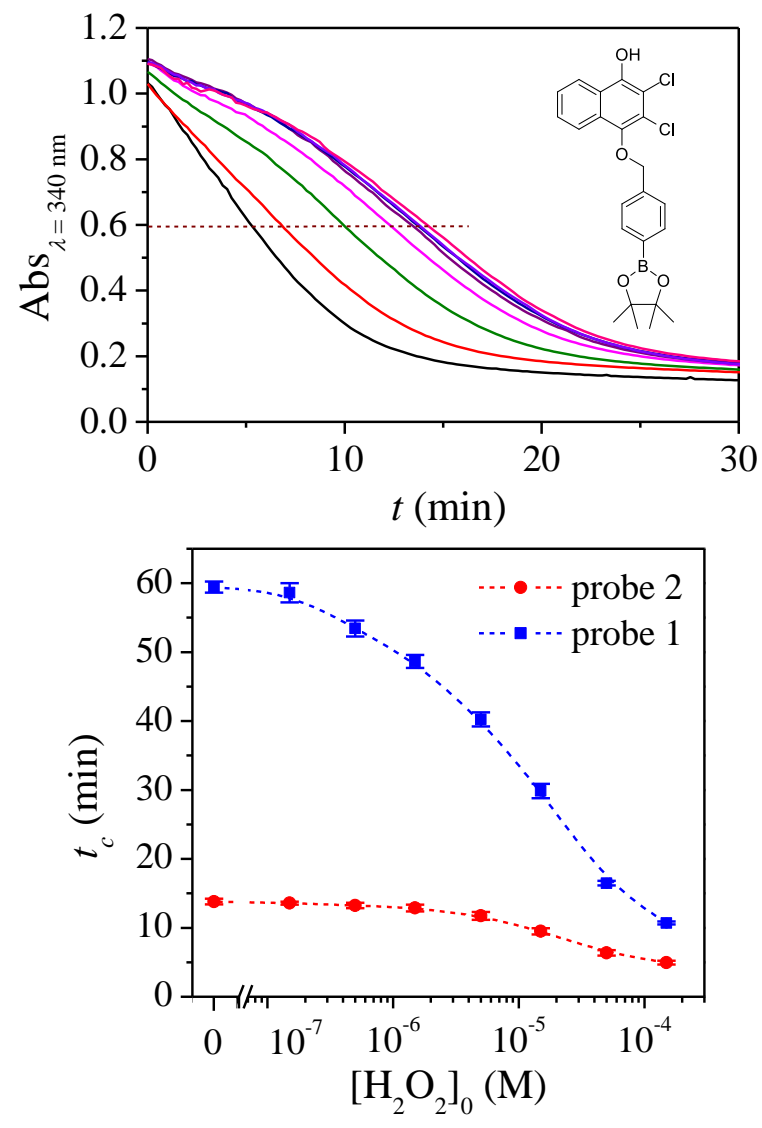

Figure 6. (Top) UV-vis kinetic traces recorded at $340 \mathrm{~nm}$ (monitoring of $\mathrm{NADH}$ consumption) in a 96-wells microtiter plate. All experiments were conducted in an air-saturated $0.1 \mathrm{M}$ Tris buffer $(\mathrm{pH} 8.5)$ containing $10 \mu \mathrm{M}$ EDTA, $50 \mu \mathrm{M} 2$, $10 \mathrm{nM} \mathrm{DI}, 250 \mu \mathrm{M} \mathrm{NADH}$ and the following $\mathrm{H}_{2} \mathrm{O}_{2}$ concentrations (from left to right): (black) 150, (red) 50, (olive) 15, (magenta) 5, (purple) 1.5, (royal) 0.5, (blue) 0.15 , and (magenta) $0 \mu \mathrm{M}$. (Bottom) Semi-logarithmic $\mathrm{H}_{2} \mathrm{O}_{2}$ calibration curve obtained by reporting (red dots) the threshold time recovered from the crossing of the horizontal dashed line in $\mathrm{A}$ as a function of $\mathrm{H}_{2} \mathrm{O}_{2}$ concentration. Errors bars correspond to standard deviations from triplicates. For comparison, the data obtained with probe 1 (blue squares) under the same experimental conditions are added (same data than in Figure 1D). 
instability of the self-immolative protecting group installed on the pro-RCC) is amplified as effectively as the 1,4-NQ specifically released through reaction with $\mathrm{H}_{2} \mathrm{O}_{2}$. This also demonstrates that such an issue cannot be solved by simply changing the nature of the naphthyl core. We may therefore conclude that improvement of the system will compulsorily necessitate the design of alternative caging strategies, much stable chemically and less prone to self-deprotection.

\section{Conclusions}

In summary, the present work demonstrates the feasibility of building a simple molecular autocatalytic reaction network based on two cross-activated catalytic loops, necessitating only a $\mathrm{H}_{2} \mathrm{O}_{2}$-sensitive probe and a reducing agent in a mild aqueous media. The relevance of such autocatalytic reaction scheme is exemplified with the triggering of the autocatalytic process by $\mathrm{H}_{2} \mathrm{O}_{2}$, leading to the simple and sensitive detection of submicromolar $\mathrm{H}_{2} \mathrm{O}_{2}$ concentrations. A very simple all-molecular format is proposed by taking advantage of ascorbate as a reducing agent and UV-vis absorbance as a simple read-out. Alternatively, enzymes such as DI or PQQ-GDH may equally participate in the reduction process of the redox cycling loop. So far, the best results are obtained with DI, leading to a $0.5 \mu \mathrm{M}$ $\mathrm{H}_{2} \mathrm{O}_{2}$ detection limit and a linear range over nearly two decades. An interesting feature of the system is the possibility to easily switch from a catalytic (Loop 1) to an autocatalytic (Loop $1 \times$ Loop 2) reaction scheme by simply adding a reducing agent in solution. Comparison of the two systems (Figure S2 vs. Figure 1d) highlights the relevance of the autocatalytic regime in terms of detection limit, linear range and reproducibility (time vs. absorbance). One must note that this strategy is conceptually different from the previously reported autocatalytic dentritic selfimmolative chain reactions, which all require the challenging design of a chemosensing probe capable to release by selfimmolation at least two equivalents of the trigger (directly or indirectly). ${ }^{13-17}$ Here, no such dendritic chemosensing probe is necessary because once deprotected by one equivalent of the trigger (here $\mathrm{H}_{2} \mathrm{O}_{2}$ ), the probe leads to the release of a redoxactive catalyst which then induces an over production of the trigger by redox cycling. The analytical performances of this new exponential molecular amplification is also significantly improved compared to the dendritic chain reaction, ${ }^{13}$ leading to a 10 -fold lower detection limit of $\mathrm{H}_{2} \mathrm{O}_{2}$ (i.e., $0.5 \mu \mathrm{M} \mathrm{H}_{2} \mathrm{O}_{2}$ ) in the presence of the diaphorase/NADH reducing species.

Our reported simple autocatalytic reaction network also presents great versatility. It can be used to efficiently reveal the redox cycling ability of any compound, necessitating only a RCCreleasing probe such as $\mathbf{1}$ and a reducing agent. Rapid and sensitive detection of nanomolar concentration of a RCC in a mildly basic aqueous media is also demonstrated. The nonspecific self-deprotection of the pro-RCC triggering molecules currently limits the analytical performances of the system. The design of more robust pro-RCC molecules is therefore needed to reach improved analytical performances. We believe that the present approach is particularly significant for analytical purposes but also for cell imaging or drug delivery applications, notably by taking advantage of probes or pro-drugs able to deliver in vivo the reporting/active molecule in a selective and autocatalytic manner. It could be also useful as a building block in the development of more complex chemical reaction networks such as those giving rise to complex spatiotemporal responses, including oscillations and pattern formation.Erreur! Signet non défini.

\section{Experimental Section}

\section{Material and methods}

NADH was purchased from TCl. Trizma ${ }^{\circledR}$ base (minimum $99.9 \%$ titration), EDTA (99.999\%), DMSO (anhydrous $\geq 99.9 \%$ ) and PQQ were obtained from Sigma-Aldrich. Hydrogen peroxide for analysis and D-Glucose were acquired from Acros Organics, and hydrochloric acid (37 wt.\%) was purchased from VWR. Lyophilized diaphorase I from Bacillus stearothermophilus (DI, EC 1.6.99.-) was obtained from Nipro (Japan). Before use, the mother solution of DI was centrifuged $(11000 \times \mathrm{g}, 30 \mathrm{~min}$ $4^{\circ} \mathrm{C}$ ) over a Nanosep membrane of $10 \mathrm{kDa}$ molecular weight cut-off (Pall Corporation) pre-equilibrated with PBS Buffer. The apoenzyme form of PQQ-dependent glucose dehydrogenase (PQQ-GDH) was produced by controlled expression in an E. Coli strain by N. Mano's group (University of Bordeaux, France) and reconstituted in its holo form following a published procedure ${ }^{51}$ Glucose Oxidase from Aspergillus Niger was purchased from sigma.

Standard spectrophotometric characterizations were carried out with a UV/Vis spectrophotometer Specord S600 from Analytical Jena (Jena, Germany) and a Cary Elipse Fluorescence Spectrophotometer from Agilent technologies (Santa Clara, CA, USA). A quartz cuvette with $1-\mathrm{cm}$ optical path-length was used for standard experiments. For the high throughput kinetic experiments, a Spark ${ }^{\circledR}$ multimode microplate reader from Tecan Trading AG (Männedorf, Switzerland) was used. In the case of fluorescence kinetics, the microwells were excited at $340 \mathrm{~nm}$ with a bandwidth of $20 \mathrm{~nm}$ (Tecan fluorescence filter ref 30113156) and the emission of fluorescence was recorded at $465 \mathrm{~nm}$ with a bandwidth of 35 $\mathrm{nm}$ (Tecan fluorescence filter ref 30113196). Standard Nunc 96-well UV transparent, clear flat-bottom microplates (Thermo Fisher) were used for the absorbance measurements, while Tecan's 96-well-black flat bottom microplates were used for the fluorescence experiments. The reactions were initiated by injecting $100 \mu \mathrm{L}$ solutions of different $\mathrm{H}_{2} \mathrm{O}_{2}$ concentrations into $100 \mu \mathrm{L}$ solutions containing the probe and any of the other desired reactants. The final working solution volume in each microwell was $200 \mu \mathrm{L}$. During the whole reaction, the microplates were left open to the air.

The electrochemical experiments were carried out with a computercontrolled AutoLab PGSTAT 12 potentiostat interfaced to a GPES 4.9 software (EcoChemie B.V. Utrecht, The Netherlands). A standard threeelectrode electrochemical cell was used to characterize by cyclic voltammetry the catalytic reduction of $\mathrm{O}_{2}$ by $1,4-\mathrm{NQ}$, while miniaturized three-electrode-based screen-printed electrochemical cells, similar to the ones previously used by our group,,$^{59}$ were used for monitoring the release of the 1,4-NQ during the course of an autocatalytic reaction.

The mother solutions of probes $(50 \mathrm{mM})$ were prepared in DMSO and stored in the fridge no more than 2-3 days. The ascorbate and NADH solutions were prepared from solid powder just before used, while the $\mathrm{H}_{2} \mathrm{O}_{2}$ solutions at different concentrations were prepared daily for each experiment. Unless otherwise stated, a $0.1 \mathrm{M}$ Tris buffer (prepared from Trizma $^{\circledR}$ base and $\mathrm{HCl}$ ) of $p \mathrm{H} 8.5$ containing $10 \mu \mathrm{M}$ EDTA was systematically used. For numerical simulations of kinetics, we used the COPASI software (version 4.16). ${ }^{72}$

\section{Chemical synthesis}

All chemicals for synthesis were purchased either from Sigma-Aldrich, Fischer Scientific or TCl Europe and used without further purification unless specified. Unless otherwise stated, reactions were conducted in air. Flash chromatography was performed on Kieselgel $60(35-70 \mu \mathrm{m})$ silica gel. ${ }^{1} \mathrm{H}$ and ${ }^{13} \mathrm{C}$ NMR spectra were recorded on a Bruker AC 400 $\mathrm{MHz}$ and were measured using $\mathrm{CDCl}_{3}, \mathrm{CD}_{3} \mathrm{OD}, \mathrm{CD}_{3} \mathrm{CN}$, Acetone- $\mathrm{d}_{6}$, 
DMSO- $d_{6}$ or DMF- $d_{7}$ as solvent. Multiplicities are reported as follows: $s=$ singlet, $\mathrm{d}=$ doublet, $\mathrm{t}=$ triplet, sept $=$ septuplet, $\mathrm{m}=$ multiplet, $\mathrm{bs}=$ broad singlet, $\mathrm{bd}=$ broad doublet. Chemical shifts are reported in $\delta$ units to 0.01 ppm precision for ${ }^{1} \mathrm{H}$ and $0.1 \mathrm{ppm}$ for ${ }^{13} \mathrm{C}$ using residual solvent as an internal reference. Mass spectra were measured on a MAT95S FinniganThermo spectrometer at the Institut de Chimie Moléculaire et des Matériaux, Université Paris-Sud.

Probe 1 was synthesized according to the following reaction scheme:

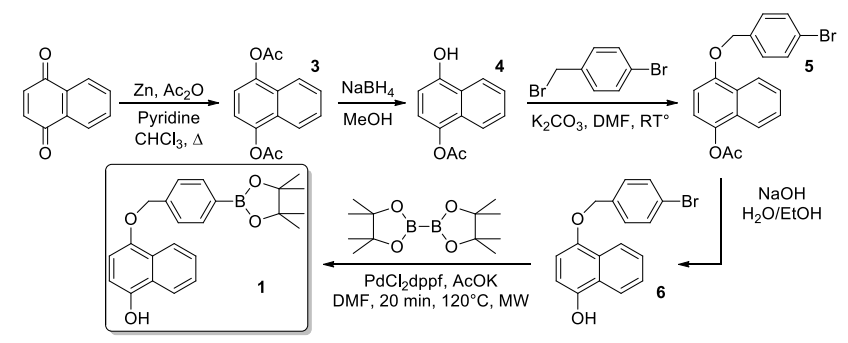

1,4-diacetoxynaphthalene 3: In a dry Schlenk and under an argon atmosphere, a mixture of 1,4-naphthoquinone $(1 \mathrm{~g}, 6.3 \mathrm{mmol})$, acetic anhydride $(1.6 \mathrm{~mL},(17.1 \mathrm{mmol})$, pyridine $(1.6 \mathrm{~mL})$ and zinc dust $(4.6 \mathrm{~g}$, $70 \mathrm{mmol}$ ) in degassed chloroform $(24 \mathrm{~mL})$ was heated at $70^{\circ} \mathrm{C}$ for $15 \mathrm{~min}$. The mixture was then cooled, filtered on celite, and the filtrate was washed twice with a $0.5 \mathrm{~N} \mathrm{HCl}$ solution, twice with water and once with brine. The organic solution was then dried over $\mathrm{Na}_{2} \mathrm{SO}_{4}$, filtered and the solvent evaporated yielding 3 as a white powder $(1.09 \mathrm{~g}, 85 \%)$. ${ }^{1} \mathbf{H}$ NMR $\left(400 \mathrm{MHz}, \mathrm{CDCl}_{3}\right): \delta=7.86(\mathrm{dd}, J=3.3$ and $6.4 \mathrm{~Hz}, 2 \mathrm{H}), 7.53$ (dd, $J=3.3$ and $6.4 \mathrm{~Hz}, 2 \mathrm{H}), 7.24(\mathrm{~s}, 2 \mathrm{H}), 2.44(\mathrm{~s}, 6 \mathrm{H})$.

1-acetoxy-4-hydroxynaphthalene 4: This compound was synthesized starting from $\mathbf{3}$ following a described procedure, ${ }^{73}$ yielding $\mathbf{4}$ as brown oil which was directly used in the next step without further purification. ${ }^{1} \mathbf{H}$ NMR $\left(400 \mathrm{MHz}, \mathrm{CDCl}_{3}\right): \delta=8.09$ (dd, $J=1.5$ and $\left.8.3 \mathrm{~Hz}, 1 \mathrm{H}\right), 7.75$ (dd, $J=1.5$ and $8.3 \mathrm{~Hz}, 1 \mathrm{H}$ ), 7.50 (ddd, $J=1.5,6.8$ and $8.3 \mathrm{~Hz}, 1 \mathrm{H}$ ) 7.46 (ddd $J=1.5,6.8$ and $8.3 \mathrm{~Hz}, 1 \mathrm{H}), 6.97(\mathrm{~d}, J=8.2 \mathrm{~Hz}, 1 \mathrm{H}), 6.56(\mathrm{~d}, J=8.2 \mathrm{~Hz}$, $1 \mathrm{H}), 5.73(\mathrm{~s}, 1 \mathrm{H}), 2.44(\mathrm{~s}, 3 \mathrm{H})$.

1-acetoxy-4-(4-bromobenzyl)oxynaphthalene 5: To a solution of 4 (819 $\mathrm{mg}, 4.1 \mathrm{mmol})$ in DMF $(11 \mathrm{~mL})$ and under an argon atmosphere were added $\mathrm{K}_{2} \mathrm{CO}_{3}(1.01 \mathrm{~g}, 6.1 \mathrm{mmol})$ and para-bromobenzyl bromide $(840 \mathrm{mg}$ $4.1 \mathrm{mmol})$. The resulting mixture was stirred for $24 \mathrm{~h}$ at room temperature. After completion of the reaction as indicated by TLC, the reaction medium was quenched with water $(41 \mathrm{~mL})$ and the resulting solution was extracted three times with ethyl acetate. The organic phases were gathered, washed twice with water and once with brine. The organic solution was then dried over $\mathrm{Na}_{2} \mathrm{SO}_{4}$, filtered and the solvent evaporated. The crude product was purified by flash chromatography (cyclohexane/ethyl acetate: 10:1) yielding 5 as a white powder $(541 \mathrm{mg}$, $36 \%) .{ }^{1} \mathrm{H}$ NMR $\left(400 \mathrm{MHz}, \mathrm{CDCl}_{3}\right): \delta=8.32(\mathrm{dd}, J=1.5$ and $7.5 \mathrm{~Hz}, 1 \mathrm{H})$, 7.75 (dd, $J=1.5$ and $7.5 \mathrm{~Hz}, 1 \mathrm{H}), 7.58-7.49(\mathrm{~m}, 4 \mathrm{H}), 7.36(\mathrm{~d}, J=8.4 \mathrm{~Hz}$, 2H), $7.13(\mathrm{~d}, J=8.3 \mathrm{~Hz}, 1 \mathrm{H}), 6.78(\mathrm{~d}, J=8.3 \mathrm{~Hz}, 1 \mathrm{H}), 5.14(\mathrm{~s}, 2 \mathrm{H}), 2.44$ (s, 3H). ${ }^{13} \mathrm{C}$ NMR $\left(100 \mathrm{MHz}, \mathrm{CDCl}_{3}\right): \delta=170.0(\mathrm{C}=\mathrm{O}), 152.4$ (C. Ar. $)$, 140.5 ( $\left.\mathrm{C}_{\text {q. Ar. }}\right), 136.1\left(\mathrm{C}_{\text {q. Ar. }}\right), 131.9$ ( $\left.\mathrm{C}_{\text {H. Ar. }}\right), 129.2$ ( $\left.\mathrm{C}_{\text {H. Ar. }}\right), 127.7$ ( $\left.\mathrm{C}_{\text {q. Ar. }}\right)$, 127.2 ( $\left.\mathrm{C}_{\text {H. Ar. }}\right), 126.5$ ( $\left.\mathrm{C}_{\text {q. Ar. }}\right), 126.1\left(\mathrm{C}_{\text {H. Ar. }}\right), 122.7\left(\mathrm{C}_{\text {H. Ar. }}\right), 122.1$ ( $\left.\mathrm{C}_{\mathrm{q} . \text { Ar. }}\right)$, 121.1 ( $\left.\mathrm{C}_{\text {H. Ar. }}\right), 117.8$ ( $\left.\mathrm{C}_{\text {H. Ar. }}\right), 104.5$ ( $\left.\mathrm{C}_{\text {H. Ar. }}\right), 69.8\left(\mathrm{CH}_{2}\right), 21.1\left(\mathrm{CH}_{3}\right)$.

1-(4-bromobenzyl)-oxy-4-hydroxynaphthalene 6: To a solution of 5 (541 $\mathrm{mg}, 1.46 \mathrm{mmol})$ in ethanol $(8.3 \mathrm{~mL})$ at $0^{\circ} \mathrm{C}$ was slowly added $7.5 \mathrm{~mL}$ of a $10 \%$ wt. $\mathrm{NaOH}$ solution. The reaction medium was stirred for $3 \mathrm{~h}$ at $0^{\circ} \mathrm{C}$ then $15 \mathrm{~mL}$ of water were added and the solution. The product was then extracted three times with chloroform and the organic phases were gathered, dried over $\mathrm{Na}_{2} \mathrm{SO}_{4}$, filtered and then concentrated. The crude product was next purified by flash chromatography (cyclohexane/ethyl acetate: $10: 1)$ to yield 6 as a white product $(262 \mathrm{mg}, 55 \%)$. ${ }^{1} \mathbf{H}$ NMR (400 $\left.\mathrm{MHz}, \mathrm{CDCl}_{3}\right): \delta=8.29-8.24(\mathrm{~m}, 1 \mathrm{H}), 8.15-8.10(\mathrm{~m}, 1 \mathrm{H}), 7.56-7.48(\mathrm{~m}, 4 \mathrm{H})$, $7.36(\mathrm{~d}, J=8.5 \mathrm{~Hz}, 2 \mathrm{H}), 6.68(\mathrm{~d}, J=8.2 \mathrm{~Hz}, 1 \mathrm{H}), 6.64(\mathrm{~d}, J=8.2 \mathrm{~Hz}, 1 \mathrm{H})$, $5.11(\mathrm{~s}, 2 \mathrm{H}), 5.03(\mathrm{~s}, 1 \mathrm{H}) .{ }^{13} \mathrm{C}$ NMR $\left(100 \mathrm{MHz}, \mathrm{CDCl}_{3}\right): \delta=148.8\left(\mathrm{C}_{\mathrm{q} . \mathrm{Ar}}\right)$, 145.7 ( $\left.\mathrm{C}_{\text {q. Ar. }}\right), 136.6$ ( $\left.\mathrm{C}_{\text {q. Ar. }}\right), 131.9$ ( $\left.\mathrm{C}_{\text {H. Ar. }}\right), 129.2$ ( $\left.\mathrm{C}_{\text {H. Ar. }}\right), 126.8$ ( $\left.\mathrm{C}_{\text {q. Ar. }}\right)$,
126.2 ( $\left.\mathrm{C}_{\text {H. Ar. }}\right), 126.2$ ( $\left.\mathrm{C}_{\text {H. Ar. }}\right), 125.6$ ( $\left.\mathrm{C}_{\text {q. Ar. }}\right), 122.3$ ( $\left.\mathrm{C}_{\text {H. Ar. }}\right), 122.0$ ( $\left.\mathrm{C}_{\text {q. Ar. }}\right)$, 121.7 ( $\left.\mathrm{C}_{\text {H. Ar. }}\right), 108.0$ ( $\left.\mathrm{C}_{\text {H. Ar. }}\right), 105.5$ ( $\left.\mathrm{C}_{\text {H. Ar. }}\right), 70.1\left(\mathrm{CH}_{2}\right)$.

1-(4-(4,4,5,5-tetramethyl-1,3,2-dioxaborolane)benzyl)oxy-4-

hydroxynaphthalene 1: In a dry microwave glass tube and under an argon atmosphere were dissolved the compound $6(100 \mathrm{mg}, 0.30 \mathrm{mmol})$ dry potassium acetate $(89 \mathrm{mg}, 0.91 \mathrm{mmol}$ ) and bis(pinacolato)diboron (116 mg, $0.46 \mathrm{mmol}$ ) in $4 \mathrm{~mL}$ of anhydrous DMF. Argon was bubbled in the reaction medium for $20 \mathrm{~min}$ then bis(acetonitrile)palladium dichloride (11 mg, $0.04 \mathrm{mmol}$ ) and 1,1'-bis(diphenylphosphino)ferrocene (24 mg, $0.04 \mathrm{mmol}$ ) were added and the bubbling was continued for $10 \mathrm{~min}$. The reaction medium was then heated in a microwave at $120^{\circ} \mathrm{C}$ for $20 \mathrm{~min}$ and was then diluted in ethyl acetate, filtered on celite and the solvent was evaporated. The crude product was directly purified by flash chromatography (hexane/ethyl acetate: 95/5) yielding $\mathbf{1}$ as a white powder $(89 \mathrm{mg}, 78 \%)$. Samples of higher purity were obtained by recrystallization of purified $\mathbf{1}$ by diffusion of pentane in diethyl ether. ${ }^{1} \mathbf{H}$ NMR $\left(400 \mathrm{MHz}, \mathrm{CDCl}_{3}\right): \delta=8.31-8.26(\mathrm{~m}, 1 \mathrm{H}), 8.13-8.08(\mathrm{~m}, 1 \mathrm{H}), 7.83$ (d, $J=8.0 \mathrm{~Hz}, 2 \mathrm{H}), 7.54-7.46(\mathrm{~m}, 4 \mathrm{H}), 6.68(\mathrm{~d}, J=8.3 \mathrm{~Hz}, 1 \mathrm{H}), 6.66(\mathrm{~d}, J$ $=8.3 \mathrm{~Hz}, 1 \mathrm{H}), 5.20(\mathrm{~s}, 2 \mathrm{H}), 4.92(\mathrm{~s}, 1 \mathrm{H}), 1.34(\mathrm{~s}, 12 \mathrm{H}) .{ }^{13} \mathrm{C}$ NMR $(100$ $\left.\mathrm{MHz}, \mathrm{CDCl}_{3}\right): \delta=148.9\left(\mathrm{C}_{\mathrm{q} . \text { Ar. }}\right), 145.7\left(\mathrm{C}_{\mathrm{q} . \text { Ar. }}\right), 140.8\left(\mathrm{C}_{\mathrm{q} . \text { Ar. }}\right), 135.2\left(\mathrm{C}_{\mathrm{H}}\right.$. Ar.), 126.8 ( $\left.\mathrm{C}_{\text {q. Ar. }}\right), 126.7$ ( $\left.\mathrm{C}_{\text {H. Ar. }}\right), 126.0$ ( $\left.\mathrm{C}_{\text {H. Ar. }}\right), 125.6$ (C ( g. Ar.), 122.4 ( $\mathrm{C}_{\mathrm{H} .}$ Ar.), 121.7 ( $\mathrm{C}_{\text {H. Ar. }}$ ), 108.0 ( $\left.\mathrm{C}_{\text {H. Ar. }}\right), 105.5$ ( $\left.\mathrm{C}_{\text {H. Ar. }}\right), 84.1\left(\mathrm{C}_{\text {q. }}\right), 70.7\left(\mathrm{CH}_{2}\right)$, $25.1\left(\mathrm{CH}_{3}\right)$. HRMS: $\mathrm{m} / \mathrm{z}$ Calculated for $\mathrm{C}_{23} \mathrm{H}_{25} \mathrm{BNaO}_{4}{ }^{+}: 399.1742$ Found: 399.1730 .

Probe $\mathbf{2}$ was synthesized according to the following reaction scheme:

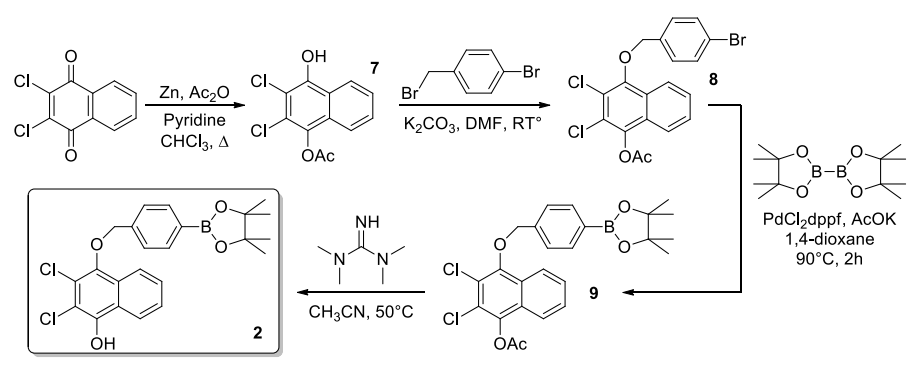

1-acetoxy-2,3-dichloro-4-hydroxynaphthalene 7: In a dry schlenk and under an argon atmosphere, a mixture of 2,3-dichloro-1,4naphthoquinone $(4 \mathrm{~g}, 17.6 \mathrm{mmol})$, acetic anhydride $(2 \mathrm{~mL}, 21.1 \mathrm{mmol})$, pyridine $(4.3 \mathrm{~mL}, 52.8 \mathrm{mmol})$ and zinc dust $(11.5 \mathrm{~g}, 176 \mathrm{mmol})$ in degased chloroform $(95 \mathrm{~mL})$ was heated at $70^{\circ} \mathrm{C}$ for $24 \mathrm{~h}$. The mixture was then cooled, filtered on celite, and the filtrate was washed twice with a $0.5 \mathrm{~N} \mathrm{HCl}$ solution, twice with water and once with brine. The organic solution was then dried over $\mathrm{Na}_{2} \mathrm{SO}_{4}$, filtered and the solvent evaporated. The crude product was then purified by flash chromatography (cyclohexane $100 \%$ to cyclohexane/ethyl acetate: $4: 1$ ) yielding 7 as a brown-red powder $(3.6 \mathrm{~g}, 75 \%)$. ${ }^{1} \mathbf{H}$ NMR $\left(400 \mathrm{MHz}, \mathrm{CDCl}_{3}\right): \delta=8.15$ (ddd, $J=0.8,1.6$ and $8.3 \mathrm{~Hz}, 1 \mathrm{H}$ ), $\delta=7.74$ (ddd, $J=0.8,1.5$ and $8.3 \mathrm{~Hz}$, $1 \mathrm{H}$ ), 7.58 (ddd, $J=1.5,6.7$ and $8.3 \mathrm{~Hz}, 1 \mathrm{H}$ ), 7.54 (ddd, $J=1.5,6.7$ and $8.3 \mathrm{~Hz}, 1 \mathrm{H}), 6.21(\mathrm{~s}, 1 \mathrm{H}), 2.53(\mathrm{~s}, 3 \mathrm{H}) .{ }^{74}$

1-acetoxy-2,3-dichloro-4-(4-bromobenzyl)oxynaphthalene 8: To a solution of $7(1.11 \mathrm{~g}, 4.1 \mathrm{mmol})$ in DMF $(11 \mathrm{~mL})$ and under an argon atmosphere were added $\mathrm{K}_{2} \mathrm{CO}_{3}(1.7 \mathrm{~g}, 12.3 \mathrm{mmol})$ and parabromobenzyl bromide $(1.5 \mathrm{~g}, 6.0 \mathrm{mmol})$. The resulting mixture was stirred overnight at room temperature. After completion of the reaction as indicated by TLC, the reaction medium was quenched with water $(41 \mathrm{~mL})$ and the resulting solution was extracted three times with ethyl acetate. The organic phases were gathered, washed twice with water and once with brine. The organic solution was then dried over $\mathrm{Na}_{2} \mathrm{SO}_{4}$, filtered and the solvent evaporated. The crude product was purified by flash chromatography (cyclohexane $100 \%$ to cyclohexane/ethyl acetate: $4: 1$ ) yielding 8 as a white powder $(1.24 \mathrm{~g}, 82 \%)$. Higher purity was reached after recrystallization in hexane (846 mg, 68\%). ${ }^{1} \mathbf{H}$ NMR $(400 \mathrm{MHz}$, $\left.\mathrm{CDCl}_{3}\right): \delta=8.05-8.01(\mathrm{~m}, 1 \mathrm{H}), \delta=7.79-7.75(\mathrm{~m}, 1 \mathrm{H}), 7.59-7.50(\mathrm{~m}, 4 \mathrm{H})$ 7.45 (d, $J=8.4 \mathrm{~Hz}, 2 \mathrm{H}), 5.07$ (s, 2H), 2.51 (s, 3H). ${ }^{13} \mathrm{C}$ NMR $(100 \mathrm{MHz}$, $\left.\mathrm{CDCl}_{3}\right): \delta=168.1(\mathrm{C}=\mathrm{O}), 150.0\left(\mathrm{C}_{\text {q. Ar. }}\right), 140.8\left(\mathrm{C}_{\mathrm{q} . \mathrm{Ar}}\right), 135.5\left(\mathrm{C}_{\mathrm{q} . \mathrm{Ar}}\right)$, 
131.8 (С. Ar.), 129.8 ( $\left.\mathrm{C}_{\text {H. Ar. }}\right), 128.0$ (С $\left.\mathrm{C}_{\text {H. Ar. }}\right), 127.6$ ( $\left.\mathrm{C}_{\text {H. Ar. }}\right), 127.6$ ( $\left.\mathrm{C}_{\mathrm{q} . \text { Ar. }}\right)$, 126.8 ( $\left.\mathrm{C}_{\text {q. Ar. }}\right), 123.7$ ( $\left.\mathrm{C}_{\mathrm{q} . \text { Ar. }}\right), 123.2$ ( $\left.\mathrm{C}_{\mathrm{q} . \text { Ar. }}\right), 122.5$ ( $\left.\mathrm{C}_{\mathrm{q} . \text { Ar. }}\right), 122.4$ ( $\left.\mathrm{C}_{\mathrm{H} . \text { Ar. }}\right)$, 121.5 ( $\left.\mathrm{C}_{\text {H. Ar. }}\right), 75.1\left(\mathrm{CH}_{2}\right), 20.5\left(\mathrm{CH}_{3}\right)$.

\section{1-acetoxy-2,3-dichloro-4-(4-(4,4,5,5-tetramethyl-1,3,2-}

dioxaborolane)benzyl)oxynaphthalene 9: In a dry Schlenk and under an argon atmosphere were dissolved the compound 8 ( $800 \mathrm{mg}, 1.8 \mathrm{mmol})$, dry potassium acetate $(535 \mathrm{mg}, 5.5 \mathrm{mmol}$ ) and bis(pinacolato)diboron (692 $\mathrm{mg}, 2.7 \mathrm{mmol}$ ) in $30 \mathrm{~mL}$ of anhydrous 1,4-dioxane. Argon was bubbled in the reaction medium for $20 \mathrm{~min}$ then bis(acetonitrile)palladium dichloride $(66 \mathrm{mg}, 0.3 \mathrm{mmol}$ ) and 1,1'-bis(diphenylphosphino)ferrocene (141 $\mathrm{mg}, 0.3 \mathrm{mmol}$ ) were added and the bubbling was continued for 10 $\min$. The reaction medium was then heated at $90^{\circ} \mathrm{C}$ for $2 \mathrm{~h}$ and was then diluted in ethyl acetate, filtered on celite and the solvent was evaporated. The crude product was directly purified by flash chromatography (hexane/ethyl acetate: 95:5) yielding 9 as a white powder which was recrystallized in hexane to afford very pure sample (160 mg, $18 \%) .{ }^{1} \mathrm{H}$ NMR $\left(400 \mathrm{MHz}, \mathrm{CDCl}_{3}\right): \delta=8.09-8.04(\mathrm{~m}, 1 \mathrm{H}), 7.88(\mathrm{~d}, J=8.0 \mathrm{~Hz}$, $2 \mathrm{H}), \delta=7.78-7.74(\mathrm{~m}, 1 \mathrm{H}), 7.58(\mathrm{~d}, J=8.0 \mathrm{~Hz}, 2 \mathrm{H}), 7.56-7.48(\mathrm{~m}, 2 \mathrm{H})$, $5.15(\mathrm{~s}, 2 \mathrm{H}), 2.51(\mathrm{~s}, 3 \mathrm{H}), 1.35(\mathrm{~s}, 12 \mathrm{H}) \cdot{ }^{13} \mathrm{C}$ NMR $\left(100 \mathrm{MHz}, \mathrm{CDCl}_{3}\right): \delta=$ $168.3(\mathrm{C}=\mathrm{O}), 150.5$ ( $\left.\mathrm{C}_{\text {q. Ar. }}\right), 140.8$ ( $\mathrm{C}_{\text {q. Ar. }}$ ), 139.7 ( $\left.\mathrm{C}_{\text {q. Ar. }}\right), 135.3$ ( $\left.\mathrm{C}_{\text {H. Ar. }}\right)$, 128.1 ( $\left.\mathrm{C}_{\text {H. Ar. }}\right), 127.9$ ( $\left.\mathrm{C}_{\text {q. Ar. }}\right), 127.8$ ( $\left.\mathrm{C}_{\text {H. Ar. }}\right), 127.5$ ( $\left.\mathrm{C}_{\text {H. Ar. }}\right), 127.0$ ( $\mathrm{C}_{\text {q. Ar. }}$ ), 123.8 ( $\mathrm{C}_{\text {q. Ar. }}$ ), 123.4 ( $\mathrm{C}_{\text {q. Ar. }}$ ), 122.8 ( $\left.\mathrm{C}_{\text {H. Ar. }}\right), 121.6$ ( $\mathrm{C}_{\text {H. Ar. }}$ ), 84.1 ( $\mathrm{C}_{\mathrm{q}}$ ), 76.0 $\left(\mathrm{CH}_{2}\right), 27.1\left(4 \times \mathrm{CH}_{3}\right), 20.7\left(\mathrm{CH}_{3}\right)$.

2,3-dichloro-1-(4-(4,4,5,5-tetramethyl-1,3,2-dioxaborolane)benzyl)oxy-4hydroxynaphthalene 2: In a dry Schlenk and under an argon atmosphere, tetramethylguanidine $(104 \mu \mathrm{L}, 1.03 \mathrm{mmol}$ ) was added to a solution of 9 $(100 \mathrm{mg}, 0.205 \mathrm{mmol})$ in degassed acetonitrile $(2.2 \mathrm{~mL})$. The reaction medium was stirred at $50^{\circ} \mathrm{C}$ for $3 \mathrm{~h}$. Upon completion of the reaction quenching with a saturated $\mathrm{NH}_{4} \mathrm{Cl}$ solution was carried out and the $\mathrm{pH}$ of the solution was then adjusted to 2 by adding $1 \mathrm{~N} \mathrm{HCl}$. The product was extracted three times with ether, the organic phases were gathered and washer once with $\mathrm{HCl} 0.1 \mathrm{~N}$. The organic solution was then dried over $\mathrm{Na}_{2} \mathrm{SO}_{4}$, filtered and the solvent evaporated. The crude product was then purified by gel filtration chromatography on Sephadex ${ }^{\mathrm{TM}}$ LH-20 using methanol as eluent. The fractions containing pure product $\mathbf{2}$ were then gathered and concentrated until a $2 \mathrm{~mL}$ methanol solution was obtained. $200 \mu \mathrm{L}$ of water was then added and the product was extracted several times with $\mathrm{n}$-hexane. Hexane extracts were gathered, dried on $\mathrm{Na}_{2} \mathrm{SO}_{4}$, filtered and concentrated. The oily residue was then dissolved in a small volume of ethanol before adding water to finally being lyophilized. Compound 2 was obtained as a slightly magenta solid (36 mg, 39\%). ${ }^{1} \mathbf{H}$ NMR $\left(400 \mathrm{MHz}, \mathrm{CDCl}_{3}\right): \delta=8.22-8.16(\mathrm{~m}, 1 \mathrm{H}), \delta=8.04-7.98(\mathrm{~m}, 1 \mathrm{H})$, $7.87(\mathrm{~d}, J=8.0 \mathrm{~Hz}, 2 \mathrm{H}), 7.57(\mathrm{~d}, J=8.0 \mathrm{~Hz}, 2 \mathrm{H}), 7.54-7.48(\mathrm{~m}, 2 \mathrm{H}), 5.99$ $(\mathrm{s}, 1 \mathrm{H}), 5.09(\mathrm{~s}, 2 \mathrm{H}), 1.35(\mathrm{~s}, 12 \mathrm{H}) \cdot{ }^{13} \mathrm{C}$ NMR $\left(100 \mathrm{MHz}, \mathrm{CDCl}_{3}\right): \delta=$ 145.7 ( $\mathrm{C}_{\text {q. Ar. }}$ ), 145.4 ( $\mathrm{C}_{\text {q. Ar. }}$ ), 140.0 ( $\mathrm{C}_{\text {q. Ar. }}$ ), 135.3 (C $\mathrm{C}_{\text {H. Ar. }}$ ), 127.9 ( $\mathrm{C}_{\text {q. Ar. }}$ ),

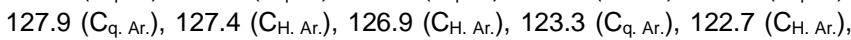
122.2 ( $\mathrm{C}_{\text {H. Ar. }}$ ), 122.1 ( $\left.\mathrm{C}_{\text {q. Ar. }}\right), 112.8\left(\mathrm{C}_{\mathrm{q}}\right), 84.1\left(\mathrm{C}_{\mathrm{q}}\right), 75.9\left(\mathrm{CH}_{2}\right), 25.1$ $\left(\mathrm{CH}_{3}\right)$. HRMS: $\mathrm{m} / \mathrm{z}$ Calculated for $\mathrm{C}_{23} \mathrm{H}_{23} \mathrm{BCl}_{2} \mathrm{NaO}_{4}{ }^{+}: 467.0963$ Found: 467.0949.

\section{Acknowledgements}

This work was supported by Agence Nationale pour la Recherche (ANR ECOSENS project- ANR-19-CE29-0022-0).

Keywords: autocatalysis $\cdot$ cross-activation $\cdot$ exponential amplification $\cdot$ redox cycling $\cdot$ autoxidation $\cdot$ naphthoquinone $\bullet$ hydrogen peroxide $\cdot$ molecular probe $\cdot$ chemosensor $\cdot$ aromatic boronate

[1] Q. Zhang, S. Bhattacharya, M. E. Andersen, Open Biology, 2013, 3, 130031.

[2] S. Goggins, C. G. Frost, Analyst, 2016, 141, 3157-218.

[3] P. Scrimin, L. J. Prins, Chem. Soc. Rev., 2011, 40, 4488-505.

[4] J. Wilhelm, A. Pingoud, ChemBioChem, 2003, 4, 1120-8
[5] M. Kubista, J. M. Andrade, M. Bengtsson, A. Forootan, J. Jonák, K. Lind, R. Sindelka, R. Sjöback, B. Sjöolive, L. Strömbom, A. Ståhlberg, N. Zoric, Mol. Aspects Med., 2006, 27, 95-125.

[6] R. Plasson, A. Brandenburg, L. Jullien, H. Bersini, J. Phys. Chem. A, 2011, 115, 8073-85.

[7] Y. Zhao, F. Chen, Q. Li, L. Wang, C. Fan, Chem. Rev., 2015, 115, 12491-545.

[8] B. J. Lam, G. F. Joyce, Nat. Biotechnol., 2009, 27, 288-92.

[9] A. J. Bisnette, S. P. Fletcher, Angew. Chem. Int., 2013, 52, 12800-26.

[10] S. N. Semenov, A. S. Y. Wong, R. M. van der Made, S. G. J. Postma, J. Groen, H. W. H. van Roekel, T. F. A. de Greef, W. T. S. Huck, Nat. Chem.,

2015, 7, 160-5.

[11] E. Valero, R. Varon, F. Garcia-Carmona, Biochem. J., 2000, 350, 23743.

[12] T.-R. Chen, C.-F. Hsu, C.-L. Chen, H. A. Witek, P. L. Urban, ACS Synthetic Biol., 2016, 5, 962-8.

[13] E. Sella, D. Shabat, J. Am. Chem. Soc., 2009, 131, 9934-6.

[14] E. Sella, R. Weinstain, R. Erez, N. Z. Burns, P. S. Baran, D. Shabat, Chem. Commun., 2010, 46, 6575-7.

[15] K. Yeung, K. M. Schmid, S. T. Phillips, Chem. Commun., 2013, 49, 394-6.

[16] J.-A. Gu, V. Mani, S.-T. Huang, Analyst, 2015, 140, 346-52.

[17] T. Yoshii, S. Onogi, H. Shigemitsu, I. Hamachi, J. Am. Chem. Soc., 2015, 137, 3360-5.

[18] M. E. Roth, O. Olive, S. Gnaim, D. Shabat, Chem. Rev., 2016, 116 $1309-52$.

[19] X. Sun, S. D. Dahlhauser, E. V. Anslyn, J. Am. Chem. Soc., 2017, 139 4635-8.

[20] S. N. Semenov, L. J. Kraft, A. Ainla, M. Zhao, M. Baghbanzadeh, V. E. Campbell, K. Kang, J. M. Fox, G. M. Whitesides, Nature, 2016, 537, 656-60.

[21] X. Sun, E. V. Anslyn, Angew. Chem. Int. Ed., 2017, 56, 9522-6.

[22] N. C. Gianneschi, S. T. Nguyen, C. A. Mirkin, J. Am. Chem. Soc., 2005, 127, 1644-5.

[23] J. P. Goertz, I. M. White, Angew. Chem. Int. Ed., 2017, 56, 13411-5.

[24] S. G. Rhee, Exp. Mol. Med., 1999, 31, 53-9.

[25] H. Sies, Redox Biol., 2017, 11, 613-9.

[26] S. N. Semenov, A. J. Markvoort, T. F. A. de Greef, W. T. S. Huck, Angew. Chem. Int. Ed., 2014, 53, 8066-9.

[27] H. W. H. van Roekel, B. J. H. M. Rosier, L. H. H. Meijer, P. A. J. Hilbers, A. J. Markvoort, W. T. S. Huck, T. F. A. de Greef, Chem. Soc. Rev., 2015, 44 7465-83.

[28] W. Hordijk, J. Theor. Biol., 2017, 435, 22-8.

[29] H. G. Kuivila, J. Am. Chem. Soc., 1954, 76, 870-4.

[30] E. W. Miller, A. E. Albers, A. Pralle, E. Y. Isacoff, C. J. Chang, J. Am

Chem. Soc., 2005, 127, 16652-9.

[31] A. Alouane, R. Labruère, T. Le Saux, F. Schmidt, L. Jullien, Angew.

Chem. Int. Ed., 2015, 54, 7492-509.

[32] J. L. M. Jourden, K. B. Daniel, S. M. Cohen, Chem. Commun., 2011, 47, 7968-70.

[33] A. R. Lippert, G. C. van de Bittner, C. J. Chang, Acc. Chem. Res., 2011 44, 793-804.

[34] K. Żamojć, M. Zdrowowicz, D. Jacewicz, D. Wyrzykowski, L.

Chmurzyński, Crit. Rev. Anal. Chem., 2016, 46, 171-200.

[35] K. B. Daniel, A. Agrawal, M. Manchester, S. M. Cohen, ChemBioChem 2013, 14, 593-8.

[36] E. Sella, D. Shabat, Org. Biomol. Chem., 2013, 11, 5074-8.

[37] V. A. Roginsky, T. K. Barsukova, H. B. Stegmann, Chem Biol. Inter.,

1999, 121, 177-97.

[38] G. D. Buffinton, K. Öllinger, A. Brunmark, E. Cadenas, Biochem. J.,

1989, 257, 561-71.

[39] C. Giulivi, E. Cadenas, Biochem. J., 1994, 301, 21-30.

[40] K. W. Wellington, RSC Adv., 2015, 5, 20309-38.

[41] L-O. Klotz, X. Hou, C. Jacob, Molecules, 2014, 19, 14902-18.

[42] P. Rana, R. Naven, A. Narayanan, Y. Will, L. H. Jones, Med. Chem.

Commun., 2013, 4, 1175-80.

[43] Y. Song, G. R. Buettner, Free Rad. Biol. Med., 2010, 49, 919-62.

[44] R. Munday, Free Rad. Biol. Med., 1997, 22, 689-95.

[45] X. Yuan, C. J. Miller, A. N. Pham, T. D. Waite, Free Rad. Biol. Med., 2014, 71, 291-302.

[46] Ž. Anusevicius, A. Ramanavicius, J. Šarlauskas, Chem. Papers, 1998, $52,643-9$.

[47] G. Silveira-Dorta, D. Manuel Monzón, F. Crisóstomo, T. S. Martín, V. Martín, R. Carrillo, Chem. Comm., 2015, 51, 7027-30.

[48] Y. Shang, C. Chen, Y. Li, J. Zhao, T. Zhu, Environ. Sci. Techol., 2012, $46,2935-42$.

[49] B. Limoges, D. Marchal, F. Mavré, J.-M. Savéant, J. Am. Chem. Soc., 2006, 128, 2084-92.

[50] Y. Ogino, K. Takagi, K. Kano, T. Ikeda, J. Electroanal. Chem., 1995, 396, 517-24.

[51] F. Durand, B. Limoges, N. Mano, F. Mavré, R. Miranda-Castro, J.-M. Savéant, J. Am. Chem. Soc., 2011, 133, 12801-9.

[52] J. Zielonka, A. Sikora, M. Hardy, J. Joseph, B. P. Dranka, B.

Kalyanaraman, Chem. Res. Toxicol., 2012, 25, 1793-9.

[53] X. Yuan, A. N. Pham, C. J. Miller, T. D. Waite, Environ. Sci. Technol., 2013, 47, 8355-64.

[54] G. R. Buettner, B. A. Jurkiewicz, Radiation Res., 1996, 145, 532-41.

[55] C. Achilli, A. Ciana, M. Fagnoni, C. Balduini, G. Minetti, Cent. Eur. J. Chem., 2013, 11, 137-9.

[56] H. G. Kuivila, J. Am. Chem. Soc., 1954, 76, 870-4. 
[57] A. Sikora, J. Zielonka, M. Lopez, J. Joseph, B. Kalyanaraman, Free

Radic. Biol. Med., 2009, 47, 1401-7.

[58] E. W. Miller, A. E. Albers, A. Pralle, E. Y. Isacoff, C. J. Chang, J. Am.

Chem. Soc., 2005, 127, 16652-9.

[59] L. Challier, R. Miranda-Castro, D. Marchal, V. Noël, F. Mavré, B.

Limoges, J. Am. Chem. Soc., 2013, 135, 14215-28.

[60] C.P. Lu, C.T. Lin, C.M. Chang, S.H. Wu, L.C. Lo, J. Agric. Food Chem.

2011, 59, 11403-6.

[61] A. Alouane, R. Labruère, T. Le Saux, I. Aujard, S. Dubruille, F. Schmidt,

L. Jullien, Chem. Eur. J., 2013, 19, 11717-24.

[62] H. G. Kuivila, Jr. J. F. Reuwer, J. A. Mangravite, Canadian J. Chem.,

1963, 41, 3081-90.

[63] P. A. Cox, M. Reid, A. G. Leach, A. D. Campbell, E. J. King, G. C.

Lloyd-Jones, J. Am. Chem. Soc., 2017, 139, 13156-65.

[64] X. Sun, D. Shabat, S. T. Phillips, E. V. Anslyn, J. Phys. Org. Chem.

2018, e3827.

[65] R. J. Wilson, A. E. Beezer, J. C. Mitchell, Thermochim. Acta., 1995,

264, 27-40.

[66] D. E. Cabelli, B. H. J. Bielski, J. Phys. Chem., 1983, 87, 1809-12.

[67] B. G. Ruiz, S. Roux, F. Courtois, C. Bonazzi, Food Res. Inter., 2018,

106, 901-8.

[68] T. V. Votyakova, I. J. Reynolds, Arch. Biochem. Biophys., 2004, 431,

138-44.

[69] K. M. Soares, N. Blackmon, T. Y. Shun, S. N. Shinde, H. K. Takyi, P.

Wipf, J. S. Lazo, P. A. Johnston, Assay Drug Dev Technol., 2010, 8, 152-74.

[70] P. A. Johnston, Curr. Opin. Chem. Biol., 2011, 15, 174-82.

[71] P. Rana, R. Naven, A. Narayanan, Y. Will, L. H. Jones,

MedChemComm, 2013, 4, 1175-80.

[72] S. Hoops, S. Sahle, R. Gauges, C. Lee, J. Pahle, N. Simus, M. Singhal,

L. Xu, P. Mendes, U. Kummer, Bioinformatics, 2006, 22, 3067-74.

[73] T. Kumamoto, N. Aoyama, S. Nakano, T. Ishikawa, Y. Narimatsu,

Tetrahedron-Asymmetry, 2001, 12, 791-95.

[74] S. Ohta, S. Hatakeyama, C. Aono, T. Koike, I. Tanimizu, H. Hirakawa

Yakugaku Zasshi, 1992, 112, 585-91. 
